\title{
C-terminal modification of fully unprotected peptide hydrazides via in situ generation of isocyanates
}

\author{
Alexander A. Vinogradov, Mark D. Simon, and Bradley L. Pentelute \\ Department of Chemistry, Massachusetts Institute of Technology, 18-596, 77 Massachusetts Avenue, Cambridge, \\ Massachusetts, 02139, United States.
}

\section{Supporting Information} Contents

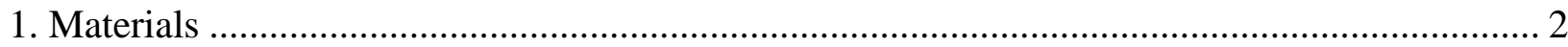

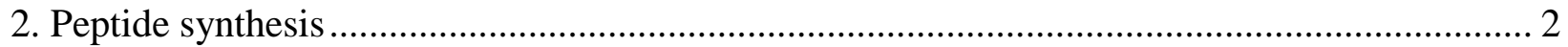

2.1. Fmoc Solid Phase Peptide Synthesis............................................................................ 2

2.2. Cleavage of peptides from resin ............................................................................... 4

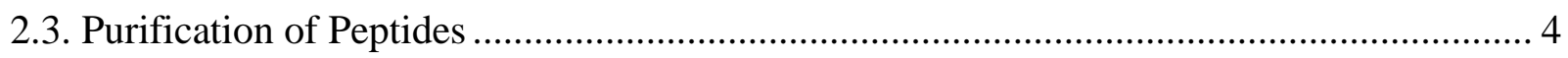

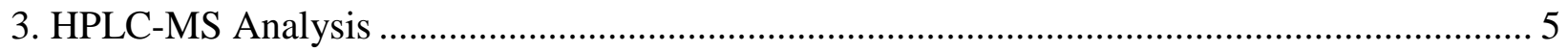

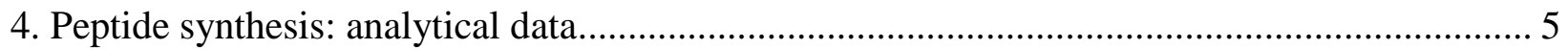

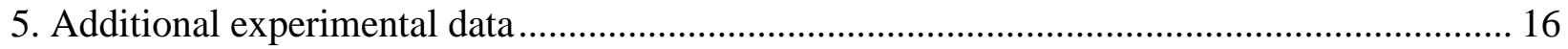

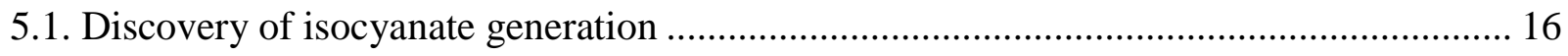

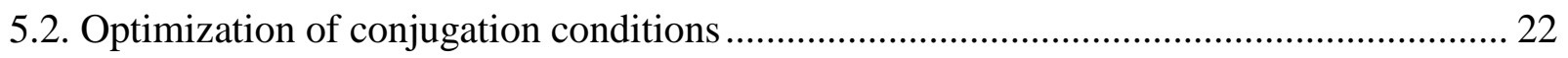

5.3. Standard reaction procedure for conjugation of nucleophiles to peptide isocyanates ....... 24

5.4. Nucleophile scope of the reaction ............................................................................... 25

5.5. Establishing the optimum nucleophile concentration for different peptide isocyanates.... 32

5.6. Experiment to detect racemization during the conjugation............................................... 33

5.7. Additional data for some C-terminal amino scan experiments ......................................... 35

5.8. Conjugation of perfluorophenylhydrazine to longer peptides.......................................... 37

5.9. Sortase A mediated ligation of peptide hydrazide to $\mathrm{LF}_{\mathrm{N}}$-DTA …….................................. 38 


\section{Materials}

2-(1H-Benzotriazol-1-yl)-1,1,3,3-tetramethyluronium hexafluorophosphate (HBTU), 2-(7Aza-1H-benzotriazole-1-yl)-1,1,3,3-tetramethyluronium hexafluorophosphate (HATU) and $\mathrm{N}^{\alpha}$ Fmoc protected D-amino acids were purchased from Chem-Impex International. $\mathrm{N}^{\alpha}$-Fmoc protected L-amino acids were obtained through Advanced ChemTech, and Novabiochem.

2-chlorotrityl chloride resin (200-400mesh, $1.2 \mathrm{mmol} / \mathrm{g})$ was purchased from Chem-Impex International and was subsequently used to prepare 2-chlorotrityl hydrazine resin adhering to the protocol reported by Stavropoulos, George et al. Letters in Peptide Science. 1995, 2, 315-318. The loading of the resin was determined to be $0.75 \mathrm{mmol} / \mathrm{g}$.

N,N-Dimethylformamide (DMF), dichloromethane (DCM), diethyl ether, and HPLC-grade acetonitrile were from EMD Millipore. Triisoproyl silane (TIPS), and 1,2-Ethanedithiol (EDT) were from Alfa Aesar. Solvents for HPLC-MS were purchased from and Fluka. All other reagents were purchased from Sigma-Aldrich. Ni-NTA Agarose beads were from Qiagen.

All reagents were used as received.

\section{Peptide synthesis}

\subsection{Fmoc Solid Phase Peptide Synthesis}

Peptides were synthesized on an enhanced version of our recently reported automated flowbased platform using a 2nd generation vessel (Simon, Heider et al. ChemBioChem, 2014, 15, 713-720). During synthesis all solvents and reagents were preheated to $60^{\circ} \mathrm{C}$ immediately before

reaching the synthesis vessel. The following standard 94 second cycle was used to assemble all peptides, unless noted:

- Amide bond formation (coupling) - 14 seconds at $23 \mathrm{~mL} / \mathrm{min}$

- Removal of coupling reagent (wash) - 30 seconds at $20 \mathrm{~mL} / \mathrm{min}$

- $\quad \mathrm{N}^{\alpha}$-Fmoc removal (deprotection) - 20 seconds at $20 \mathrm{~mL} / \mathrm{min}$

- Removal of deprotection reagent and products (wash) - 30 seconds at $20 \mathrm{~mL} / \mathrm{min}$

Coupling. Coupling was performed by delivering the following coupling solution at 20 $\mathrm{mL} / \mathrm{min}$ for $14 \mathrm{~s}$. The coupling solution consisted of of $\mathrm{N}^{\alpha}$-Fmoc and side chain protected amino 
acid dissolved in equimolar 0.4 M HBTU in DMF. To activate the amino acid, DIEA was injected at $4 \mathrm{ml} / \mathrm{min}$. The mixed fluid then passed through a static mixer and preheat loop to the synthesis vessel. In order to minimize racemization of Cys and His residues, only $2 \mathrm{ml} / \mathrm{min}$ of DIEA were injected when activating these amino acids. In all cases, this coupling solution contained at least four equivalents of activated amino acid with respect to the resin.

To bond C-terminal Val and Ile residues to the resin, $1 \mathrm{mmol}$ of protected amino acid dissolved in $2.5 \mathrm{~mL}$ of $0.4 \mathrm{M} \mathrm{HBTU}$ in DMF was manually delivered to the synthesis vessel, then synthesis was paused for 10 minutes. An increased reaction time was necessary to quantitatively couple these sterically hindered residues to the resin.

Side chain protection was as follows: $\operatorname{Arg}(\mathrm{Pbf}), \operatorname{Asn}(\mathrm{Trt}), \mathrm{Asp}(\mathrm{OtBu}), \mathrm{Cys}(\mathrm{Trt}), \mathrm{Gln}(\operatorname{Trt})$, Glu(OtBu), His(Trt), Lys(Boc), Ser(tBu), Thr(tBu), Trp(Boc), Tyr(tBu).

Wash. Excess reagent and reaction by-products were washed out from the synthesis vessel with $10 \mathrm{~mL}$ of DMF delivered at $20 \mathrm{~mL} / \mathrm{min}$ over $30 \mathrm{~s}$.

Deprotection. $\mathrm{N}^{\alpha}$-Fmoc protecting groups were removed with $6.6 \mathrm{~mL}$ of $20 \%(\mathrm{v} / \mathrm{v})$ piperidine in DMF delivered at $20 \mathrm{~mL} / \mathrm{min}$ over 20 seconds.

Three peptides: $\mathrm{H}_{2} \mathrm{~N}$-Ala-Gln-Val-Ile-Asn-Thr-Phe-Asp-Gly-Val-CONHNH $\mathrm{C}_{2}, \quad \mathrm{H}_{2} \mathrm{~N}$-AlaLys-Val-Ile-Asn-Thr-Phe-Asp-Gly-Ile-CONHNH${ }_{2}$, and $\mathrm{H}_{2} \mathrm{~N}$-Ala-His-Val-Ile-Asn-Thr-Phe-AspGly-Thr-CONHNH${ }_{2}$ were synthesized on the manual version of the flow system, described in the same manuscript. The synthesis procedure was similar, except $0.38 \mathrm{M}$ HATU was used as an activator, and the following three minute synthetic cycle was used:

- Amide bond formation (coupling) - 30 seconds at $6 \mathrm{~mL} / \mathrm{min}$

- Removal of coupling reagent (wash) -60 seconds at $20 \mathrm{~mL} / \mathrm{min}$

- $\mathrm{N}^{\alpha}$-Fmoc removal (deprotection) -20 seconds at $20 \mathrm{~mL} / \mathrm{min}$

- Removal of deprotection reagent and products (wash) -60 seconds at $20 \mathrm{~mL} / \mathrm{min}$

Peptide $\quad \mathrm{H}_{2} \mathrm{~N}$-Ala-Gln-Val-Ile-Asn-Thr-Phe-Asp-Gly-Val-CONHNH ${ }_{2} \quad$ was additionally synthesized on a larger scale using standard batch Fmoc SPPS procedures: 2.5g of Chlorotrityl hydrazide resin $(0.25 \mathrm{mmol} / \mathrm{g})$ was pre-swollen in DCM for 30 minutes, then drained. To bond Cterminal Val to the resin, $5 \mathrm{mmol}$ of Fmoc protected valine was dissolved in $12.5 \mathrm{~mL}$ of $0.38 \mathrm{M}$ HATU in DMF and $1.5 \mathrm{~mL}$ of DIEA, then added to the swollen resin. After 1.5 hours, the resin 
was drained and a second $5 \mathrm{mmol}$ aliquot of Fmoc-Val-OH, prepared as above, was added. After a second 1.5 hour coupling, the resin was drained and washed three times with $30 \mathrm{~mL}$ of DMF each. Fmoc was removed by treatment with $20 \mathrm{~mL}$ of $20 \%$ piperidine in DMF for 20 minutes, and the resin was drained and washed with DMF three times $(30 \mathrm{~mL}$ each). Synthesis then proceeded according to the following procedure: 5mmol of each protected amino acid was dissolved in $12.5 \mathrm{~mL}$ of $0.38 \mathrm{M}$ HATU in DMF and $1.5 \mathrm{~mL}$ of DIEA, then added to the resin. After a 30 minute coupling step, the resin was drained and washed with DMF three times $(30 \mathrm{~mL}$ each). Fmoc was removed by treatment with $30 \mathrm{~mL}$ of $20 \%$ piperidine in DMF for 20 minutes, and the resin was again drained and washed as above. After the final Fmoc removal, the resin was washed four times with $40 \mathrm{~mL}$ of DCM each, and dried in vacuo.

All other peptides mentioned herein were synthesized and purified as described previously in Mong, Vinogradov et al, ChemBioChem, 2014, 15, 721-733.

\subsection{Cleavage of peptides from resin}

All peptides were cleaved from the resin and side chain deprotected with a standard cleavage cocktail of $2.5 \%(\mathrm{v} / \mathrm{v})$ EDT, $2.5 \%(\mathrm{v} / \mathrm{v}) \mathrm{H}_{2} \mathrm{O}$, and $1 \%(\mathrm{v} / \mathrm{v})$ TIPS in TFA for 7 minutes at $60{ }^{\circ} \mathrm{C}$. In all cases, compressed nitrogen was used to evaporate the cleavage solution to dryness together with resin. The resulting mixtures were triturated and washed three times with cold diethyl ether, and, unless noted, dissolved in $95 \%$ water / 5\% acetonitrile $(0.1 \%$ TFA added). Resin was filtered and solutions were purified without intermediate lyophilization.

\subsection{Purification of Peptides}

All peptides were purified on a Waters 600 HPLC system with a Waters 484 or 486 UV detector using water with $0.1 \%$ TFA added (solvent $\mathrm{A}$ ) and acetonitrile with $0.1 \%$ TFA added (solvent B) as solvents.

An Agilent Zorbax 300SB preparative $C_{3}$ column $(300 \AA, 7 \mu \mathrm{m}, 21.2 \times 250 \mathrm{~mm})$ was used at

$20 \mathrm{~mL} / \mathrm{min}$ linear flow rate for the purification of peptide hydrazides. Unless noted, the following gradient was used to purify peptide hydrazides: $5 \% \mathrm{~B}$ in A for 5 minutes, then $5 \%$ $35 \%$ B ramping linearly over 90 minutes. 
An Agilent Zorbax 300SB semi-preparative C3 column (300 $\AA, 5 \mu \mathrm{m}, 9.4$ x $250 \mathrm{~mm}$ ) was used at $5 \mathrm{~mL} / \mathrm{min}$ linear flow rate for the purification of isocyanate conjugation reactions. Unless noted, the following gradient was used to purify isocyanate conjugation reactions: $5 \% \mathrm{~B}$ in $\mathrm{A}$ for 10 minutes; then $5 \%-15 \%$ B ramping linearly over 10 minutes; then $15 \%-45 \%$ B ramping linearly over 90 minutes.

Fractions were collected and screened for the desired material using HPLC-ESI-TOF.

\section{HPLC-MS Analysis}

Unless noted, all peptides, proteins and reaction mixtures were analyzed on an Agilent 6520 Accurate Mass Q-TOF LC-MS using an Agilent Zorbax 300SB C 3 column $(300 \AA$, $5 \mu \mathrm{m}, 2.1 \mathrm{x}$ $150 \mathrm{~mm}$ ) run with the following method. At $40{ }^{\circ} \mathrm{C}$ and a flow rate of $0.8 \mathrm{~mL} / \mathrm{min}$, the following gradient was used: $1 \%$ acetonitrile with $0.1 \%$ formic acid added (FA, solvent B') in water with $0.1 \%$ FA (solvent A') for $2 \mathrm{~min}, 1-61 \%$ B' in A' ramping linearly over $11 \mathrm{~min}, 61 \%$ B' in A' for 1 minute. Typically, $100-1000 \mu \mathrm{g} / \mathrm{mL}$ solutions of peptides and proteins were subject to analysis. More concentrated solutions were diluted to appropriate concentrations with $50 \%$ $\mathrm{A} / 50 \% \mathrm{~B}$. Unless noted, all chromatograms shown in this work are plots of total ion current (TIC) versus time. HPLC yields of reactions were calculated via manual integration of the area under peaks corresponding to reaction products on TIC vs. time chromatograms. Generally, TIC and $\mathrm{UV}_{214}$ integration gave converging results, consistent with previous reports (D. Cohen, C. Zhang, et al. JACS, 2015, 137, 9784-9787); TIC integration was a preferred method of

characterization for practical reasons. The data were analyzed using Agilent MassHunter Qualitative analysis software. All MS deconvolution spectra were obtained using the maximum entropy algorithm.

\section{Peptide synthesis: analytical data}

\section{1. $\mathrm{H}_{2} \mathrm{~N}$-Ala-Gln-Val-Ile-Asn-Thr-Phe-Asp-Gly-Val-CONHNH${ }_{2}$}

The peptide was synthesized and purified as described above (Section 2) on $180 \mathrm{mg}$ of resin. The crude peptide was lyophilized to give $105 \mathrm{mg}$ of crude peptide. $26.2 \mathrm{mg}$ of pure peptide was obtained after purification. 
The batch synthesis of this peptide additionally yielded $140 \mathrm{mg}$ of pure compound after lyophilization.

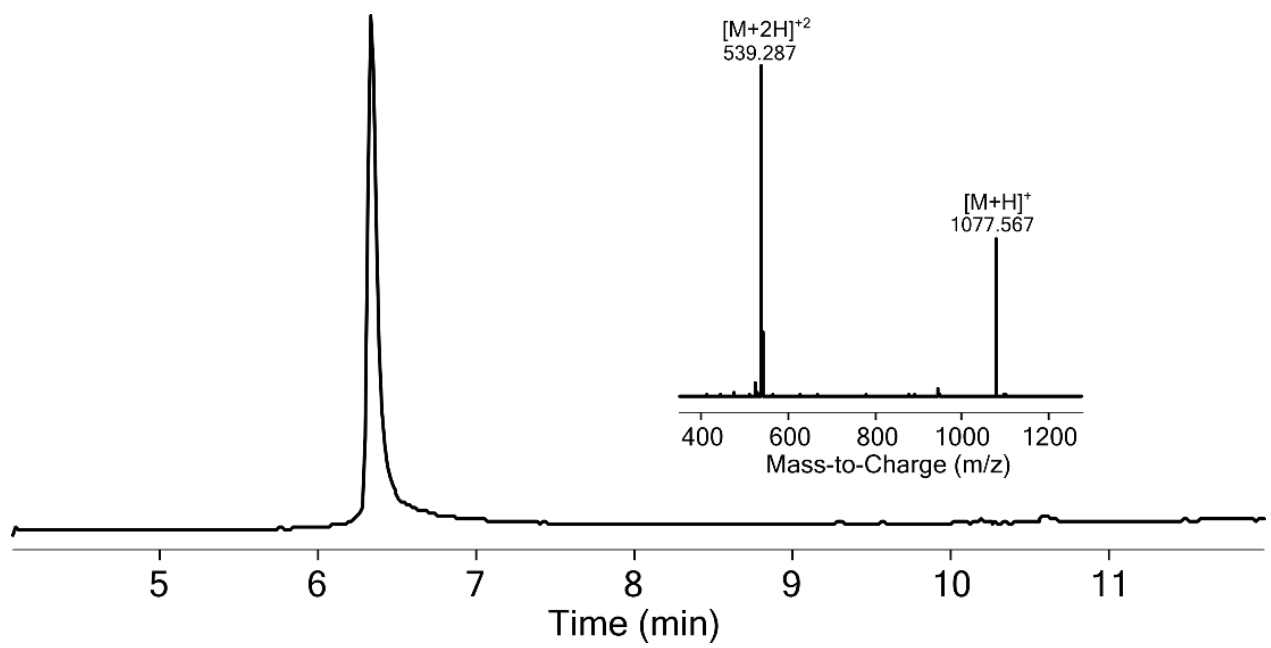

Figure S1. HPLC-MS (TIC) chromatogram for the purified peptide $\mathrm{H}_{2} \mathrm{~N}-\mathrm{Ala}-\mathrm{Gln}$-Val-Ile-Asn-Thr-Phe-Asp-Gly-Val-CONHNH 2 with MS inset on the right. Calc. monoisotopic mass $=1076.6 \mathrm{Da}$.

\section{2. $\mathrm{H}_{2} \mathrm{~N}$-Ala-Lys-Val-Ile-Asn-Thr-Phe-Asp-Gly-Ile-CONHNH${ }_{2}$}

The peptide was synthesized and purified as described above (Section 2) on $190 \mathrm{mg}$ of resin. Purification of crude peptide yielded $16.5 \mathrm{mg}$ of pure peptide after lyophilization.

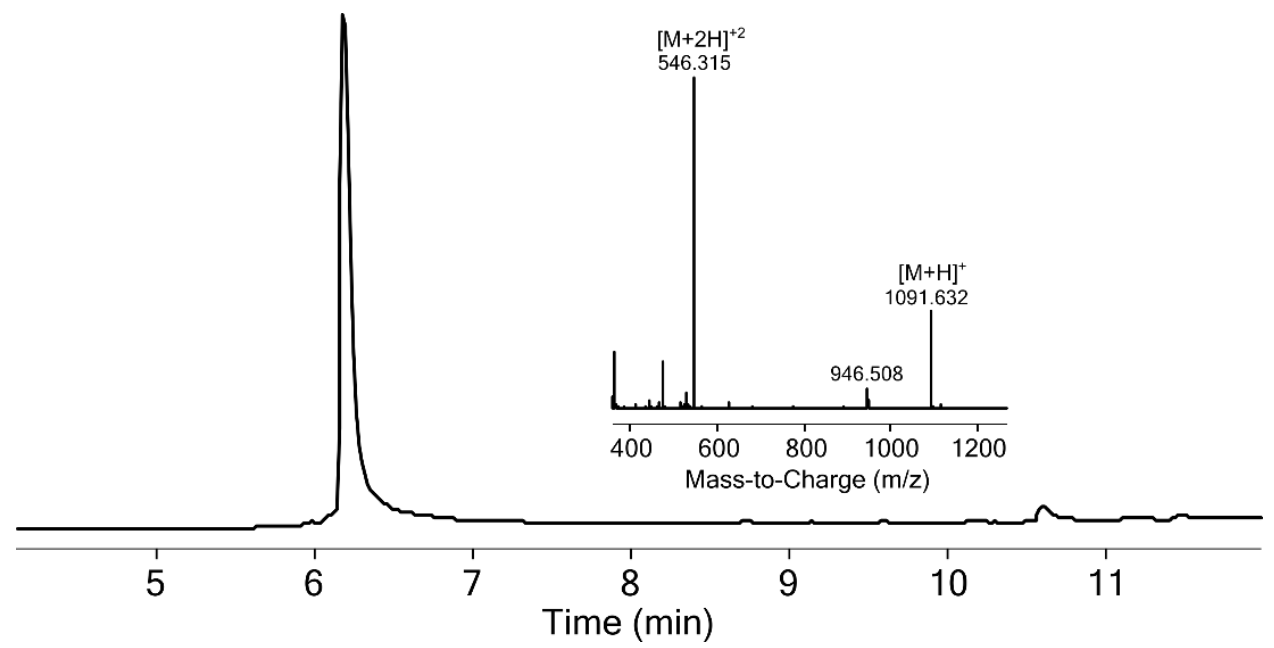

Figure S2. HPLC-MS (TIC) chromatogram for the purified peptide $\mathrm{H}_{2} \mathrm{~N}$-Ala-Lys-Val-Ile-Asn-Thr-Phe-Asp-Gly-Ile-CONHNH 2 with MS inset on the right. Calc. monoisotopic mass =1090.6 Da.

\section{3. $\mathrm{H}_{2} \mathrm{~N}$-Ala-His-Val-Ile-Asn-Thr-Phe-Asp-Gly-Thr-CONHNH${ }_{2}$}


The peptide was synthesized and purified as described above (Section 2) on $180 \mathrm{mg}$ of resin. Purification of crude peptide yielded $16.2 \mathrm{mg}$ of pure peptide after lyophilization.

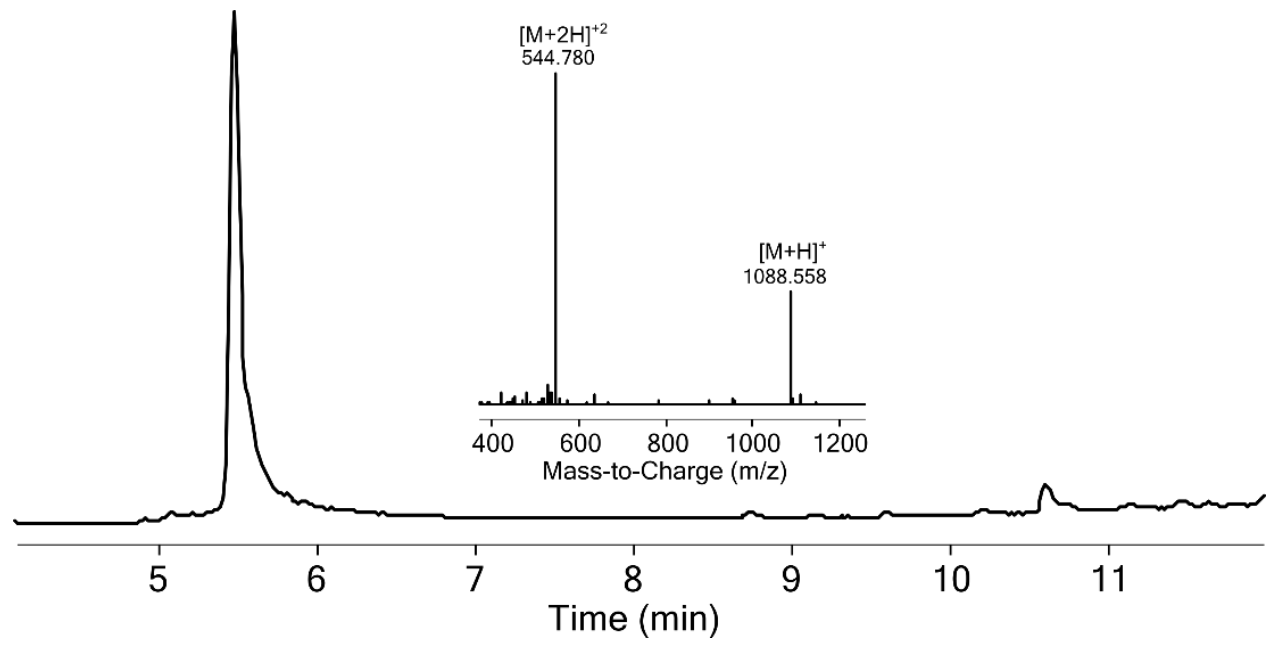

Figure S3. HPLC-MS (TIC) chromatogram for the purified peptide $\mathrm{H}_{2} \mathrm{~N}$-Ala-His-Val-Ile-Asn-Thr-Phe-Asp-Gly-Thr-CONHNH with MS inset on the right. Calc. monoisotopic mass $=1087.54 \mathrm{Da}$.

\section{4. $\mathrm{H}_{2} \mathrm{~N}$-Ala-Lys-Val-Ile-Asn-Thr-Phe-Asp-Gly-Trp-CONHNH}

The peptide was synthesized and purified as described above (Section 2) on $239 \mathrm{mg}$ of resin. Purification of crude peptide yielded $4.5 \mathrm{mg}$ of pure peptide after lyophilization.

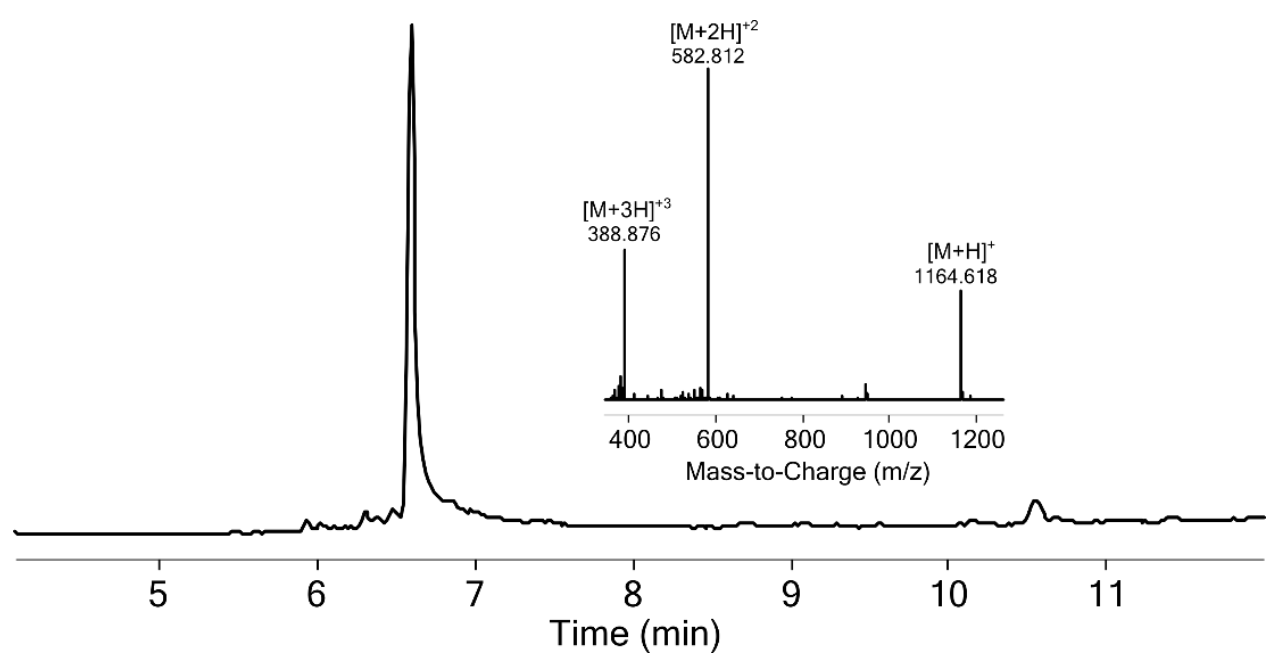

Figure S4. HPLC-MS (TIC) chromatogram for the purified peptide $\mathrm{H}_{2} \mathrm{~N}$-Ala-Lys-Val-Ile-Asn-Thr-Phe-Asp-Gly-Trp-CONHNH 2 with MS inset on the right. Calc. monoisotopic mass $=1163.6 \mathrm{Da}$.

\section{5. $\mathrm{H}_{2} \mathrm{~N}$-Ala-Trp-Val-Ile-Asn-Thr-Phe-Asp-Gly-Arg-CONHNH ${ }_{2}$}


The peptide was synthesized and purified as described above (Section 2) on $232 \mathrm{mg}$ of resin. Purification of crude peptide yielded $3.8 \mathrm{mg}$ of pure peptide after lyophilization.

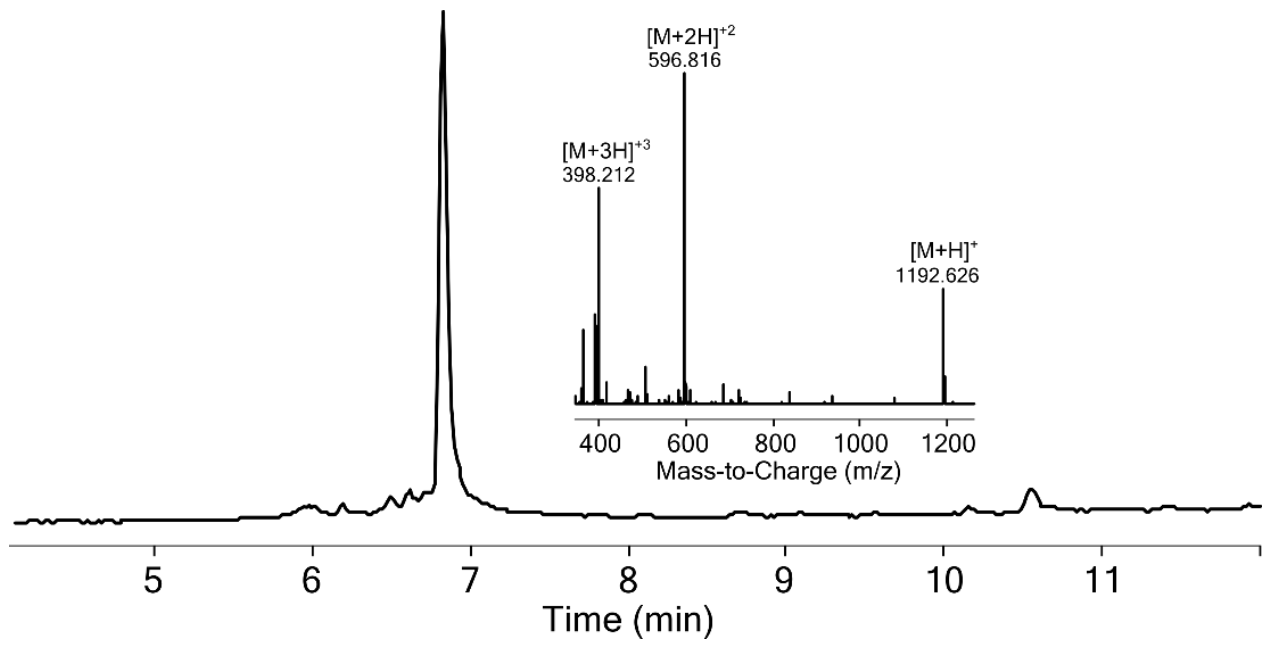

Figure S5. HPLC-MS (TIC) chromatogram for the purified peptide $\mathrm{H}_{2} \mathrm{~N}-\mathrm{Ala}-\mathrm{Trp}-\mathrm{Val}-\mathrm{Ile}$-Asn-Thr-Phe-Asp-Gly-Arg-CONHNH 2 with MS inset on the right. Calc. monoisotopic mass = 1091.6 Da.

\section{6. $\mathrm{H}_{2} \mathrm{~N}$-Ala-Tyr-Val-Ile-Asn-Thr-Phe-Asp-Gly-Lys-CONHNH${ }_{2}$}

The peptide was synthesized and purified as described above (Section 2) on $370 \mathrm{mg}$ of resin. Purification of crude peptide yielded $18.5 \mathrm{mg}$ of pure peptide after lyophilization.

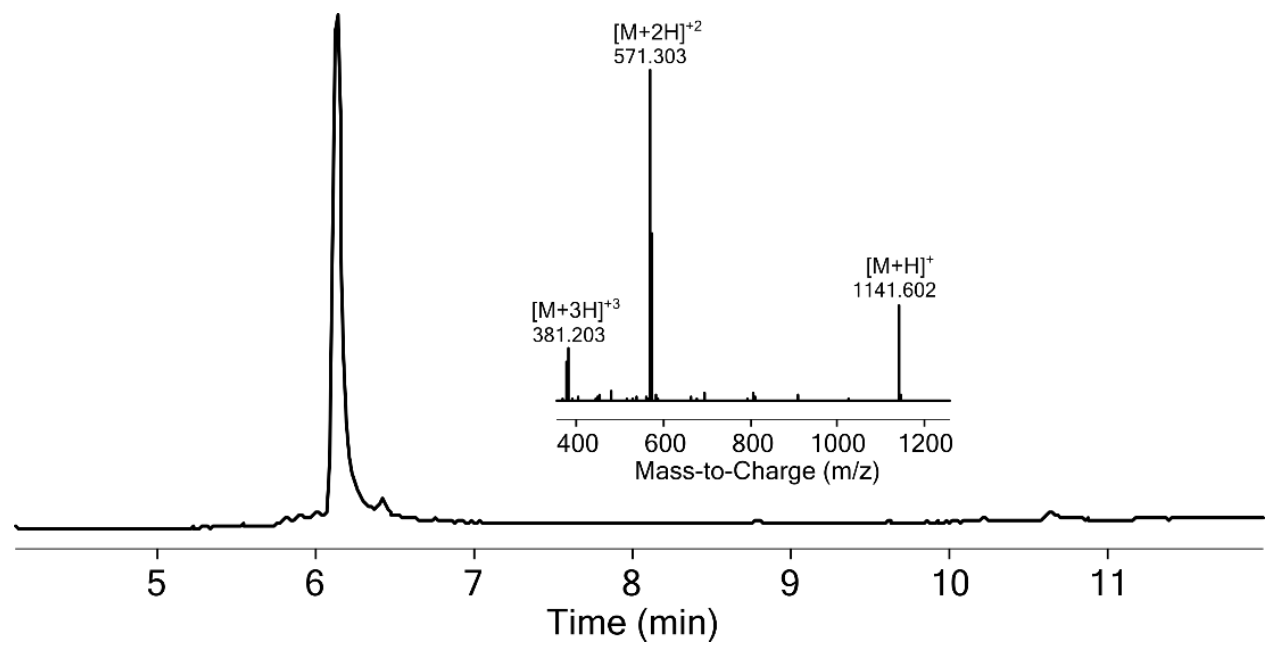

Figure S6. HPLC-MS (TIC) chromatogram for the purified peptide $\mathrm{H}_{2} \mathrm{~N}-\mathrm{Ala}-\mathrm{Gln}-\mathrm{Val}-\mathrm{Ile}-\mathrm{Asn}-\mathrm{Thr}-\mathrm{Phe}-\mathrm{Asp}-\mathrm{Gly}-\mathrm{Val}-\mathrm{CONHNH} 2$ with MS inset on the right. Calc. monoisotopic mass = 1076.6 Da.

\section{7. $\mathrm{H}_{2} \mathrm{~N}$-Ala-Asp-Val-Ile-Asn-Thr-Phe-Asp-Gly-Leu-CONHNH}


The peptide was synthesized and purified as described above (Section 2) on $225 \mathrm{mg}$ of resin. Purification of crude peptide yielded $4.4 \mathrm{mg}$ of pure peptide after lyophilization.

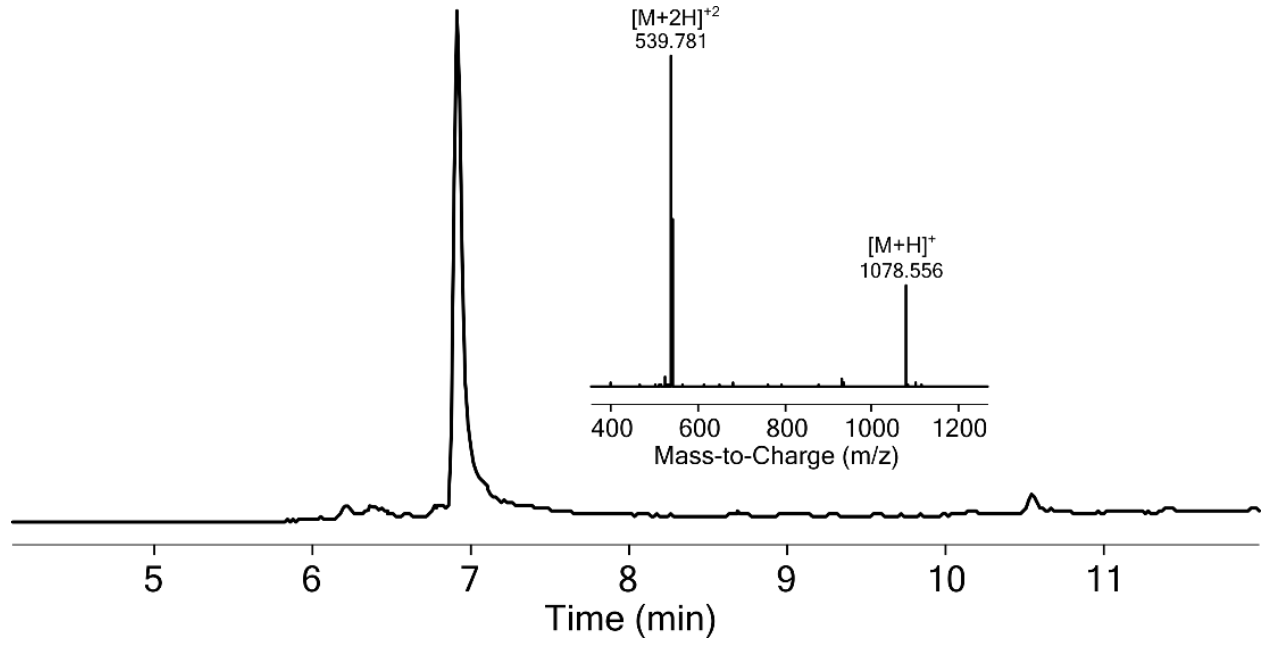

Figure S7. HPLC-MS (TIC) chromatogram for the purified peptide $\mathrm{H}_{2} \mathrm{~N}-\mathrm{Ala}-\mathrm{Asp}-\mathrm{Val}-\mathrm{Ile}-\mathrm{Asn}$-Thr-Phe-Asp-Gly-Leu-CONHNH${ }_{2}$ with MS inset on the right. Calc. monoisotopic mass $=1077.54 \mathrm{Da}$.

\section{8. $\mathrm{H}_{2} \mathrm{~N}$-Ala-Gly-Val-Ile-Asn-Thr-Phe-Asp-Gly-Met-CONHNH${ }_{2}$}

The peptide was synthesized and purified as described above (Section 2) on $386 \mathrm{mg}$ of resin. Purification of crude peptide yielded $9.1 \mathrm{mg}$ of pure peptide after lyophilization.

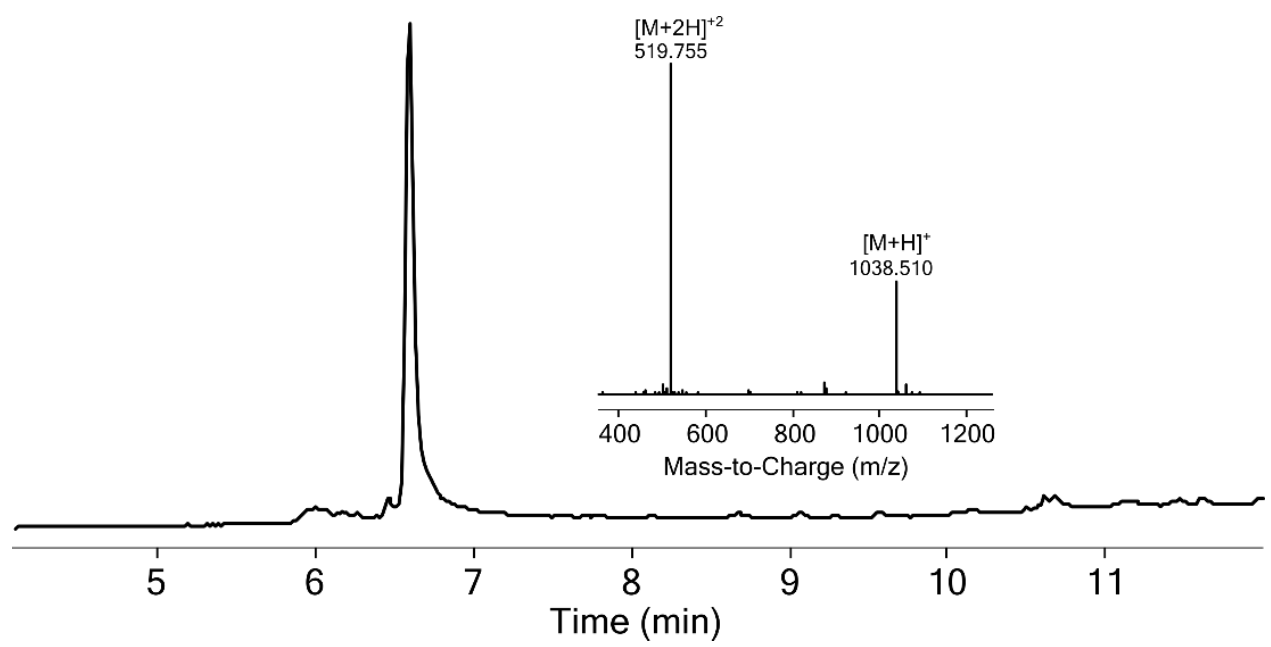

Figure S8. HPLC-MS (TIC) chromatogram for the purified peptide $\mathrm{H}_{2} \mathrm{~N}-\mathrm{Ala}-\mathrm{Gly}-\mathrm{Val}-\mathrm{Ile}-\mathrm{Asn}-\mathrm{Thr}-\mathrm{Phe}-\mathrm{Asp}-\mathrm{Gly}-\mathrm{Met}-\mathrm{CONHNH} 2$ with MS inset on the right. Calc. monoisotopic mass = 1037.5 Da.

4.9. $\mathrm{H}_{2} \mathrm{~N}$-Ala-Glu-Val-Ile-Asn-Thr-Phe-Asp-Gly-Ala-CONHNH 
The peptide was synthesized and purified as described above (Section 2) on $182 \mathrm{mg}$ of resin. Purification of crude peptide yielded $20.0 \mathrm{mg}$ of pure peptide after lyophilization.

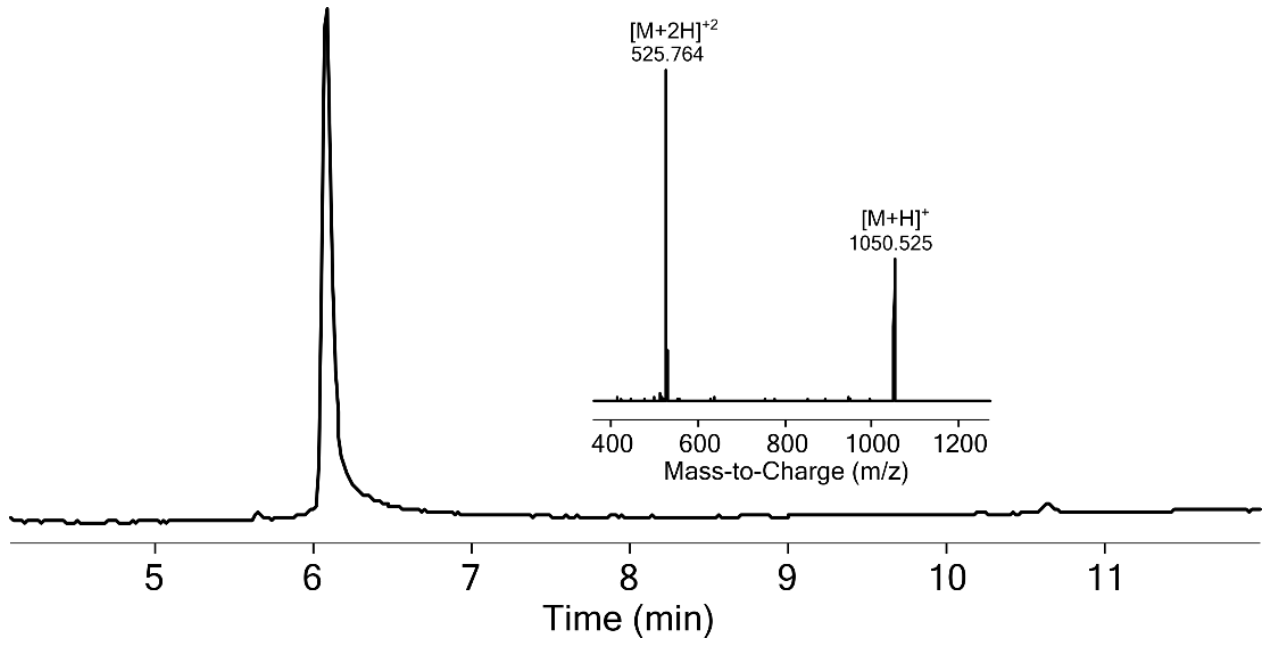

Figure S9. HPLC-MS (TIC) chromatogram for the purified peptide $\mathrm{H}_{2} \mathrm{~N}-\mathrm{Ala}-\mathrm{Glu}-\mathrm{Val}-\mathrm{Ile}-\mathrm{Asn}-\mathrm{Thr}-\mathrm{Phe}-\mathrm{Asp}-\mathrm{Gly}-\mathrm{Ala}-\mathrm{CONHNH} 2$ with MS inset on the right. Calc. monoisotopic mass = 1049.5 Da.

\subsection{0. $\mathrm{H}_{2} \mathrm{~N}-\mathrm{Ala}-$ Val-Val-Ile-Asn-Thr-Phe-Asp-Gly-His-CONHNH${ }_{2}$}

The peptide was synthesized and purified as described above (Section 2) on $260 \mathrm{mg}$ of resin. Purification of crude peptide yielded $5.5 \mathrm{mg}$ of pure peptide after lyophilization.

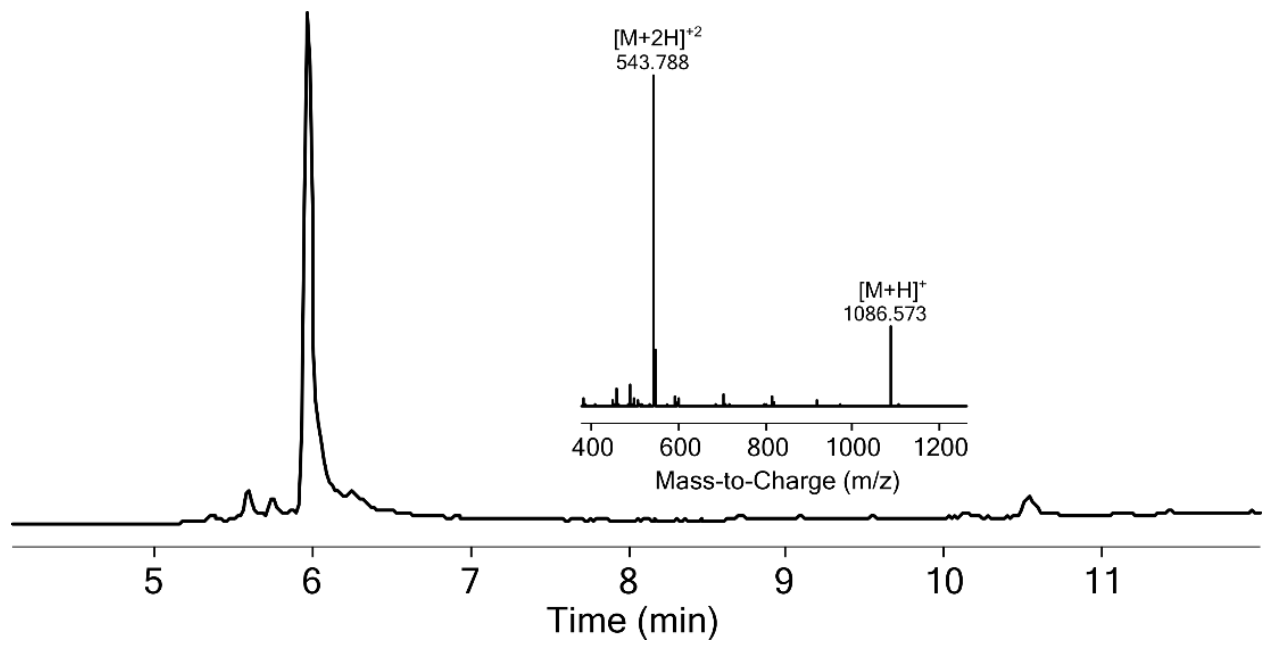

Figure S10. HPLC-MS (TIC) chromatogram for the purified peptide $\mathrm{H}_{2} \mathrm{~N}$-Ala-Val-Val-Ile-Asn-Thr-Phe-Asp-Gly-His$\mathrm{CONHNH}_{2}$ with $\mathrm{MS}$ inset on the right. Calc. monoisotopic mass $=1085.6 \mathrm{Da}$.

\subsection{1. $\mathrm{H}_{2} \mathrm{~N}$-Ala-Met-Val-Ile-Asn-Thr-Phe-Asp-Gly-Phe-CONHNH}


The peptide was synthesized and purified as described above (Section 2) on $385 \mathrm{mg}$ of resin. Purification of crude peptide yielded $12.4 \mathrm{mg}$ of pure peptide after lyophilization.

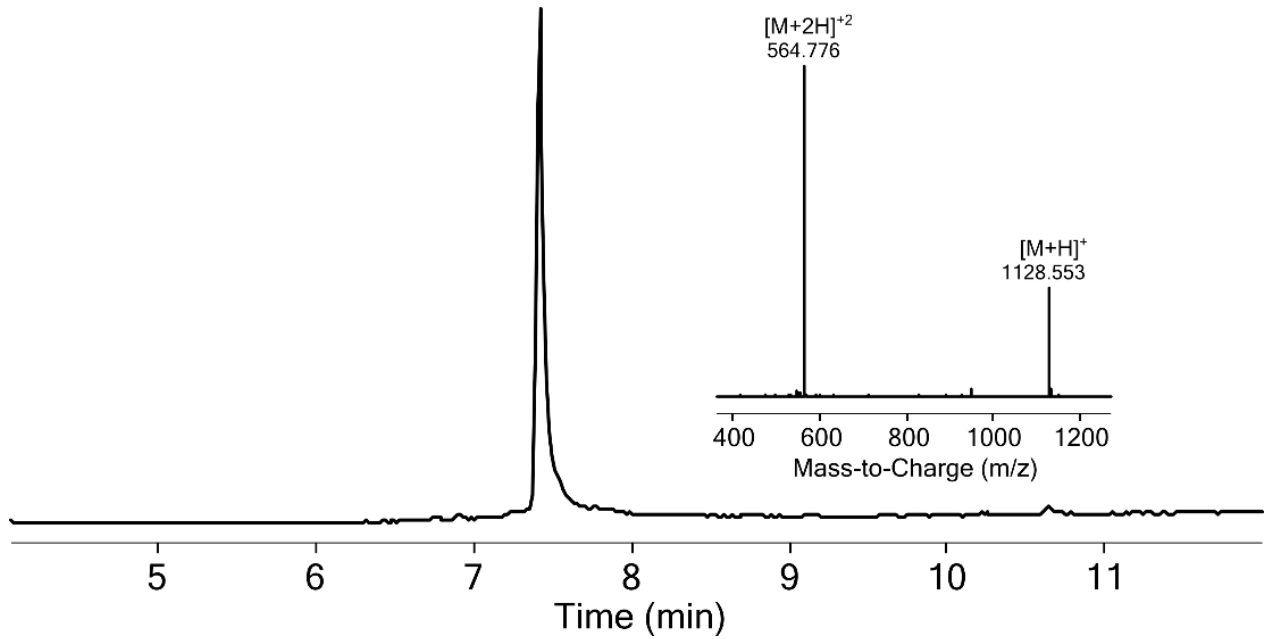

Figure S11. HPLC-MS (TIC) chromatogram for the purified peptide $\mathrm{H}_{2} \mathrm{~N}-\mathrm{Ala}-\mathrm{Met}-\mathrm{Val}$-Ile-Asn-Thr-Phe-Asp-Gly-Phe$\mathrm{CONHNH}_{2}$ with MS inset on the right. Calc. monoisotopic mass $=1127.54 \mathrm{Da}$.

\subsection{2. $\mathrm{H}_{2} \mathrm{~N}$-Ala-Lys-Val-Ile-Asn-Thr-Phe-Asp-Gly-Pro-CONHNH${ }_{2}$}

The peptide was synthesized and purified as described above (Section 2) on $236 \mathrm{mg}$ of resin. Purification of crude peptide yielded $3.7 \mathrm{mg}$ of pure peptide after lyophilization.

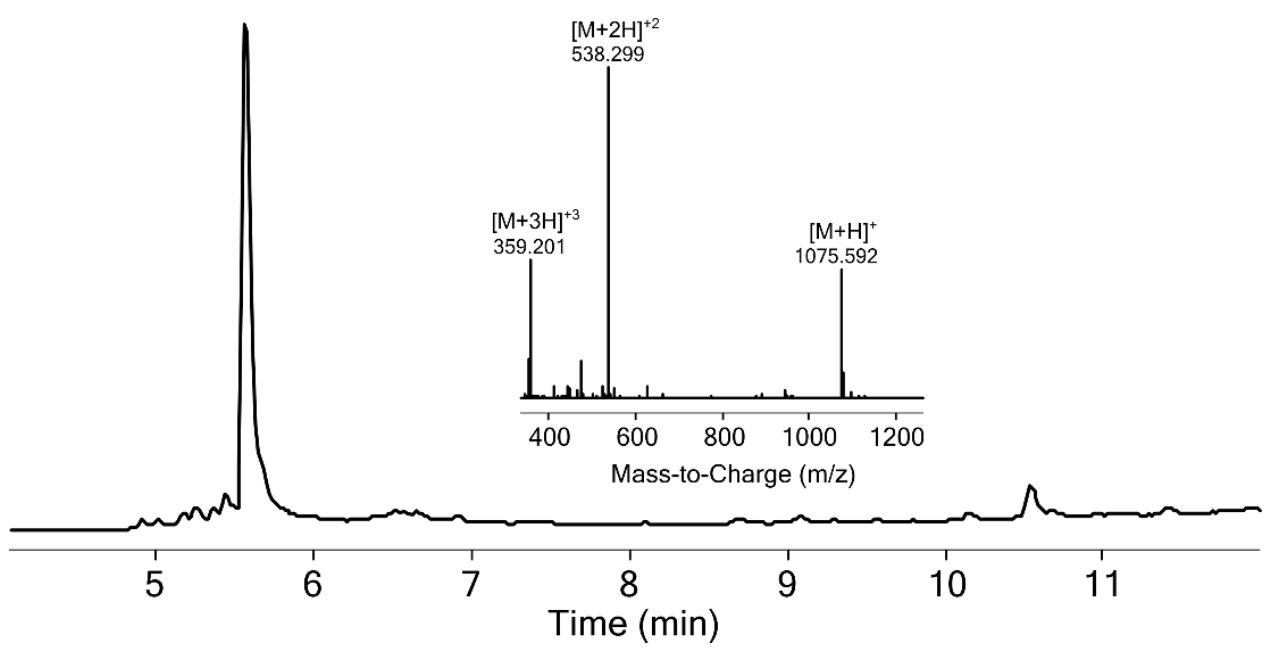

Figure S12. HPLC-MS (TIC) chromatogram for the purified peptide $\mathrm{H}_{2} \mathrm{~N}$-Ala-Lys-Val-Ile-Asn-Thr-Phe-Asp-Gly-Pro$\mathrm{CONHNH}_{2}$ with MS inset on the right. Calc. monoisotopic mass $=1074.6 \mathrm{Da}$.

\subsection{3. $\mathrm{H}_{2} \mathrm{~N}$-Ala-Ser-Val-Ile-Asn-Thr-Phe-Asp-Gly-Gly-CONHNH${ }_{2}$}


The peptide was synthesized and purified as described above (Section 2) on $194 \mathrm{mg}$ of resin. Purification of crude peptide yielded $10.5 \mathrm{mg}$ of pure peptide after lyophilization.

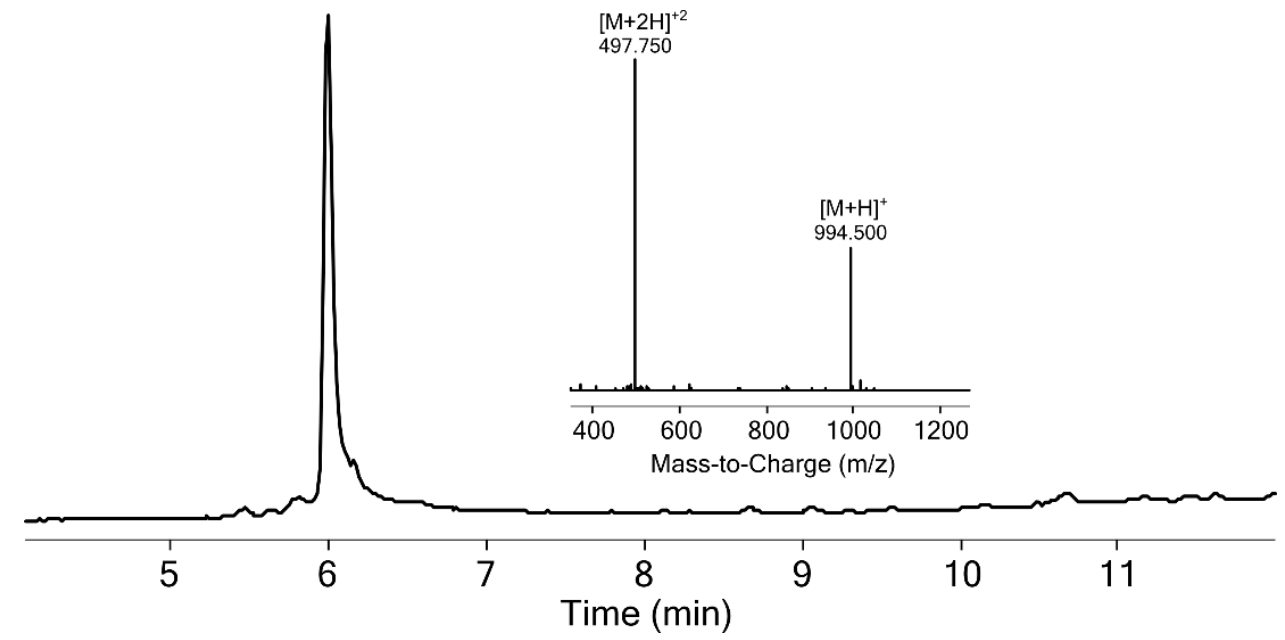

Figure S13. HPLC-MS (TIC) chromatogram for the purified peptide $\mathrm{H}_{2} \mathrm{~N}$-Ala-Ser-Val-Ile-Asn-Thr-Phe-Asp-Gly-Gly$\mathrm{CONHNH}_{2}$ with MS inset on the right. Calc. monoisotopic mass $=993.5 \mathrm{Da}$.

\subsection{4. $\mathrm{H}_{2} \mathrm{~N}$-Ala-Asn-Val-Ile-Asn-Thr-Phe-Asp-Gly-Ser-CONHNH 2}

The peptide was synthesized and purified as described above (Section 2) on $180 \mathrm{mg}$ of resin. Purification of crude peptide yielded $5.6 \mathrm{mg}$ of pure peptide after lyophilization.

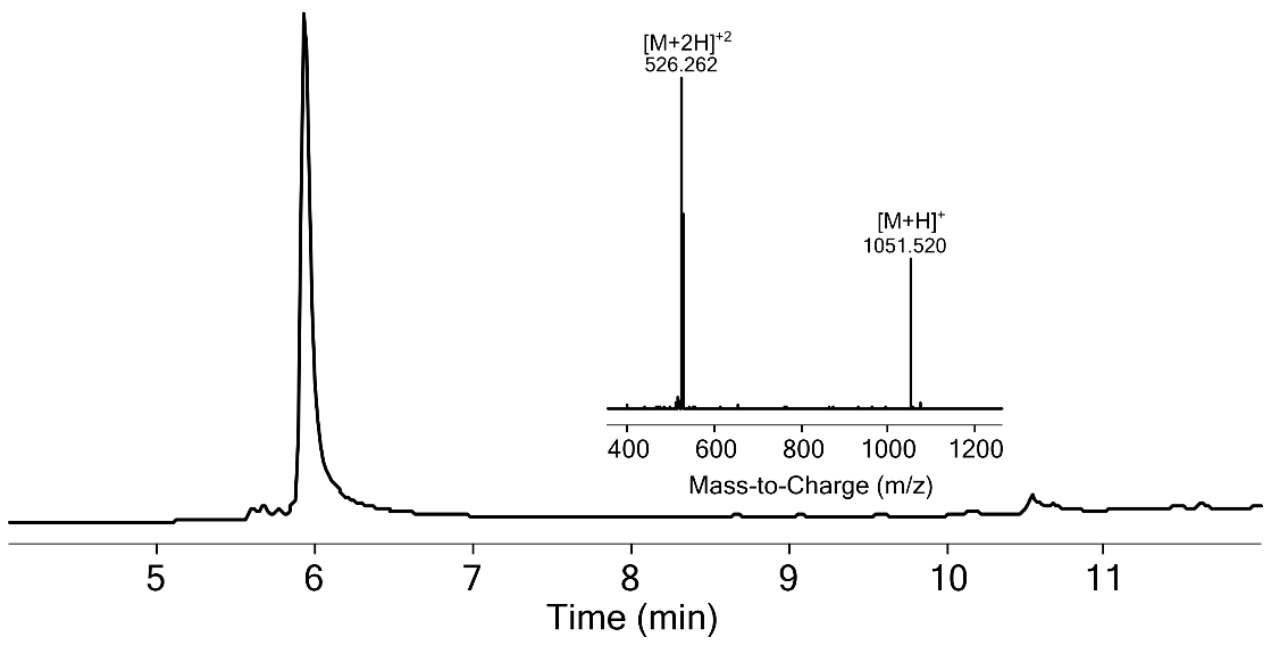

Figure S14. HPLC-MS (TIC) chromatogram for the purified peptide $\mathrm{H}_{2} \mathrm{~N}$-Ala-Asn-Val-Ile-Asn-Thr-Phe-Asp-Gly-Ser$\mathrm{CONHNH}_{2}$ with $\mathrm{MS}$ inset on the right. Calc. monoisotopic mass $=1050.5 \mathrm{Da}$.

\subsection{5. $\mathrm{H}_{2} \mathrm{~N}$-Ala-Arg-Val-Ile-Asn-Thr-Phe-Asp-Gly-Tyr-CONHNH${ }_{2}$}


The peptide was synthesized and purified as described above (Section 2) on $390 \mathrm{mg}$ of resin. Purification of crude peptide yielded $28.0 \mathrm{mg}$ of pure peptide after lyophilization.

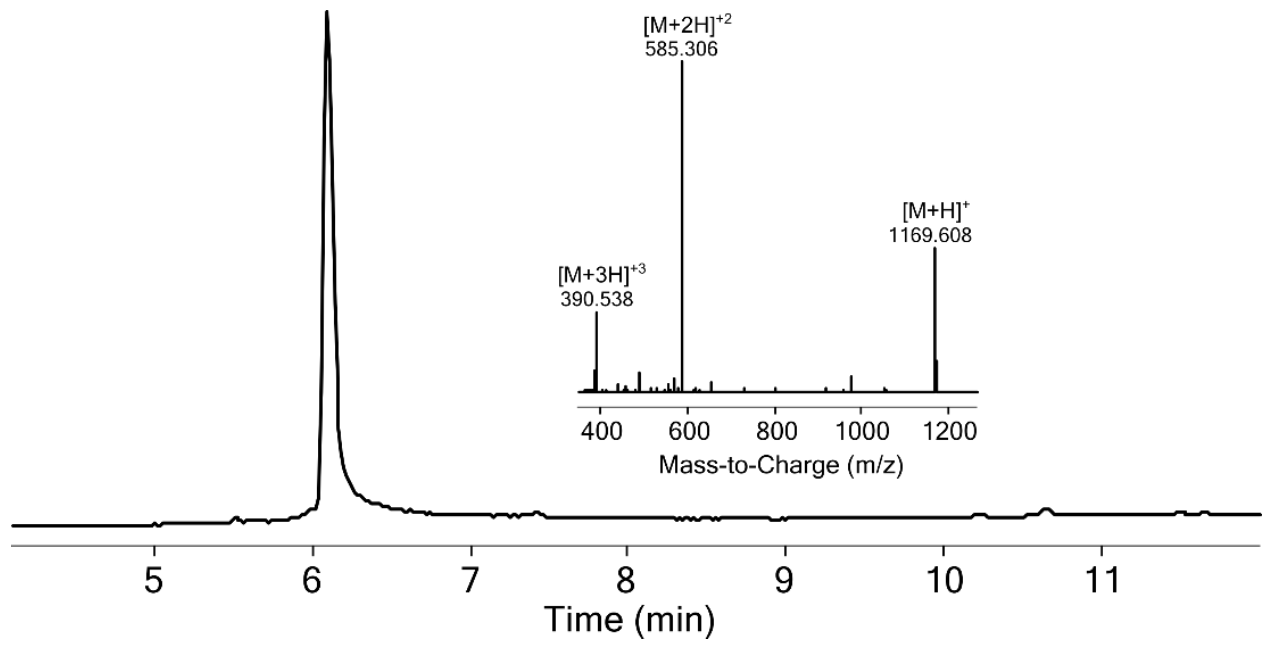

Figure S15. HPLC-MS (TIC) chromatogram for the purified peptide $\mathrm{H}_{2} \mathrm{~N}$-Ala-Arg-Val-Ile-Asn-Thr-Phe-Asp-Gly-Tyr$\mathrm{CONHNH}_{2}$ with MS inset on the right. Calc. monoisotopic mass $=1168.6 \mathrm{Da}$.

\subsection{6. $\mathrm{H}_{2} \mathrm{~N}$-Ala-Pro-Val-Ile-Asn-Thr-Phe-Asp-Gly-Cys-CONHNH${ }_{2}$}

The peptide was synthesized and purified as described above (Section 2) on $244 \mathrm{mg}$ of resin. Purification of crude peptide yielded $2.8 \mathrm{mg}$ of pure peptide after lyophilization.

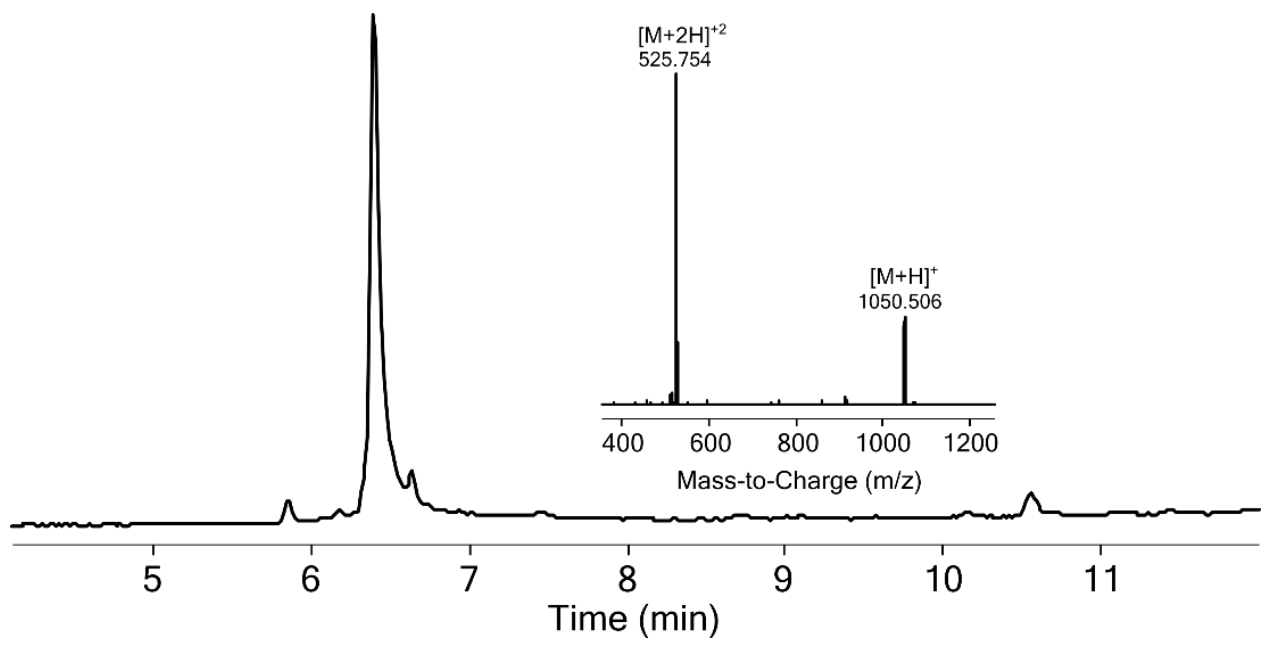

Figure S16. HPLC-MS (TIC) chromatogram for the purified peptide $\mathrm{H}_{2} \mathrm{~N}$-Ala-Pro-Val-Ile-Asn-Thr-Phe-Asp-Gly-Cys$\mathrm{CONHNH}_{2}$ with MS inset on the right. Calc. monoisotopic mass $=1049.5 \mathrm{Da}$.

\subsection{7. $\mathrm{H}_{2} \mathrm{~N}$-Ala-Leu-Val-Ile-Asn-Thr-Phe-Asp-Gly-Glu-CONHNH${ }_{2}$}


The peptide was synthesized and purified as described above (Section 2) on $396 \mathrm{mg}$ of resin. Purification of crude peptide yielded $11.8 \mathrm{mg}$ of pure peptide after lyophilization.

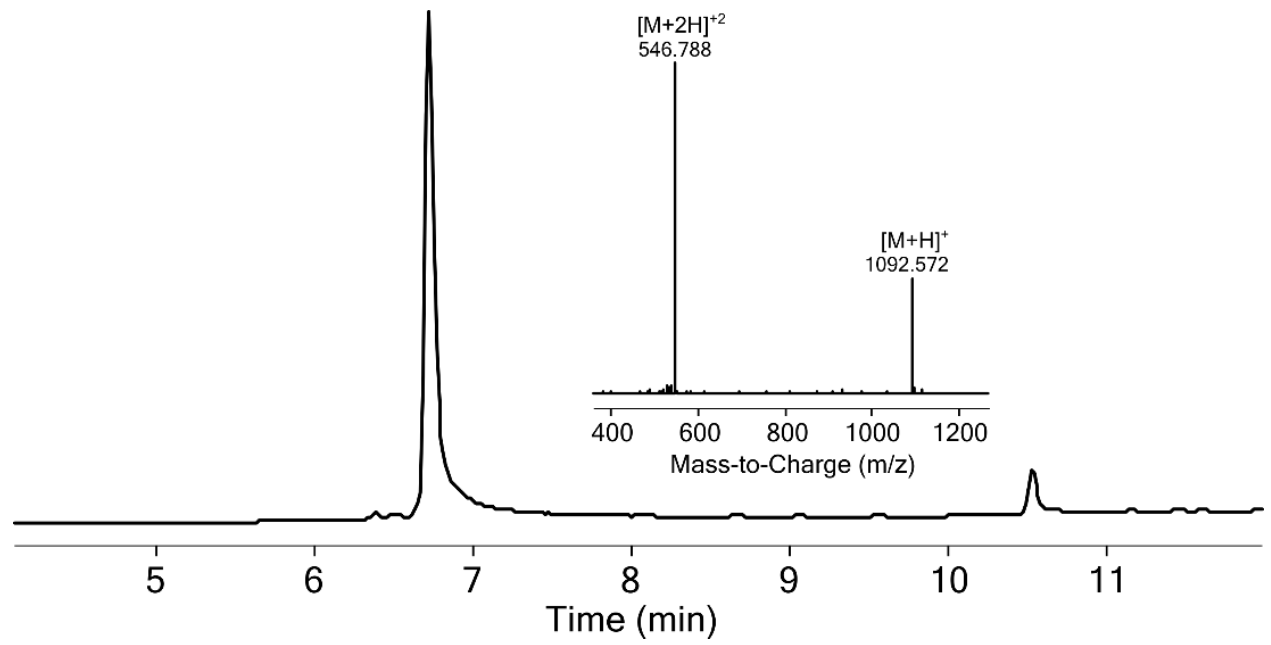

Figure S17. HPLC-MS (TIC) chromatogram for the purified peptide $\mathrm{H}_{2} \mathrm{~N}$-Ala-Leu-Val-Ile-Asn-Thr-Phe-Asp-Gly-Glu$\mathrm{CONHNH}_{2}$ with MS inset on the right. Calc. monoisotopic mass $=1091.6 \mathrm{Da}$.

\subsection{8. $\mathrm{H}_{2} \mathrm{~N}$-Ala-Gln-Val-Ile-Asn-Thr-Phe-Asp-Gly- ${ }^{\mathrm{D}}$ Val-CONHNH${ }_{2}$}

The peptide was synthesized as described above (Section 2) on $204 \mathrm{mg}$ of resin, lyophilized and used without further purification. Lyophilization afforded $97 \mathrm{mg}$ of peptide.

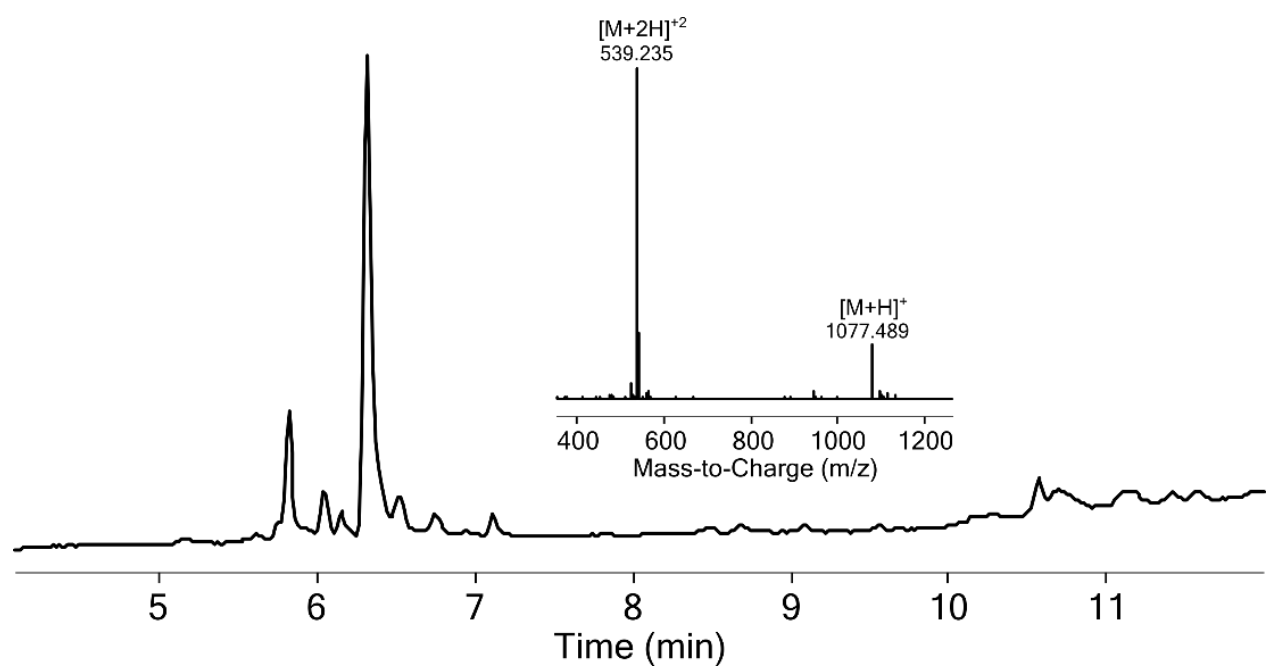

Figure S18. HPLC-MS (TIC) chromatogram for crude $\mathrm{H}_{2} \mathrm{~N}$-Ala-Gln-Val-Ile-Asn-Thr-Phe-Asp-Gly- ${ }^{\mathrm{D}}$ Val-CONHNH 2 with $\mathrm{MS}^{-}$ inset on the right. Calc. monoisotopic mass $=1076.6 \mathrm{Da}$.

4.19. Peptides with Asp, Asn and Gln on the C-terminus 
$\mathrm{H}_{2} \mathrm{~N}$-Ala-Ala-Val-Ile-Asn-Thr-Phe-Asp-Gly-Asp-CONHNH${ }_{2}, \quad \mathrm{H}_{2} \mathrm{~N}$-Ala-Cys-Val-Ile-Asn-ThrPhe-Asp-Gly-Asn-CONHNH${ }_{2}$, and $\mathrm{H}_{2} \mathrm{~N}$-Ala-Ile-Val-Ile-Asn-Thr-Phe-Asp-Gly-Gln-CONHNH 2 were synthesized as described above. However, during cleavage and handling of the peptides, even at low $\mathrm{pH}$, we observed an intramolecular cyclization that prevented us from isolating the desired hydrazides (Fig. S19). This side-reaction, accompanying synthesis of C-terminal hydrazides of Asp, Asn, and Gln, was described in detail by Fang, Li et al. Angew. Chem. Int. Ed. 2011, 50, 7645 -7649.

a)
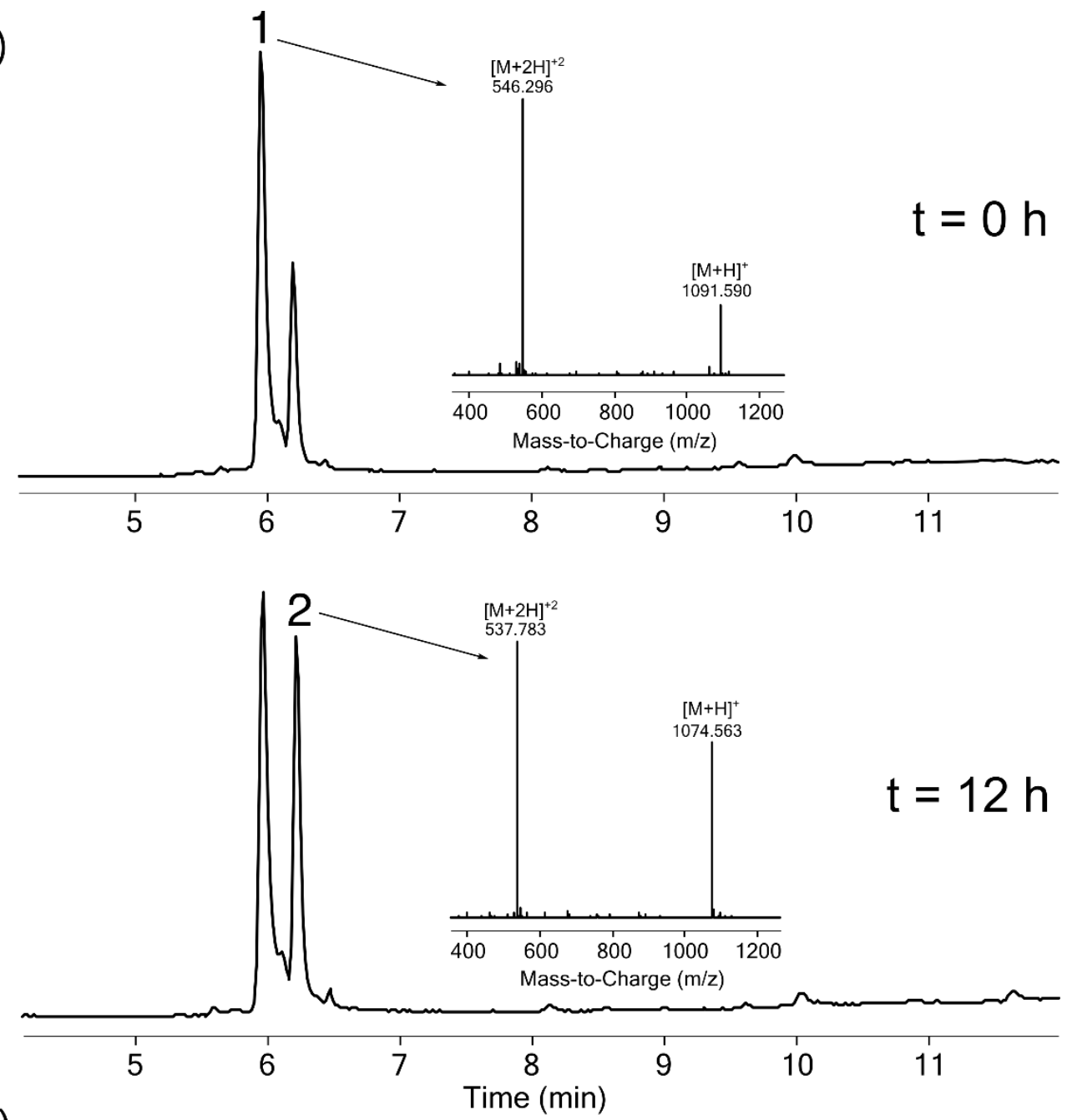

b)

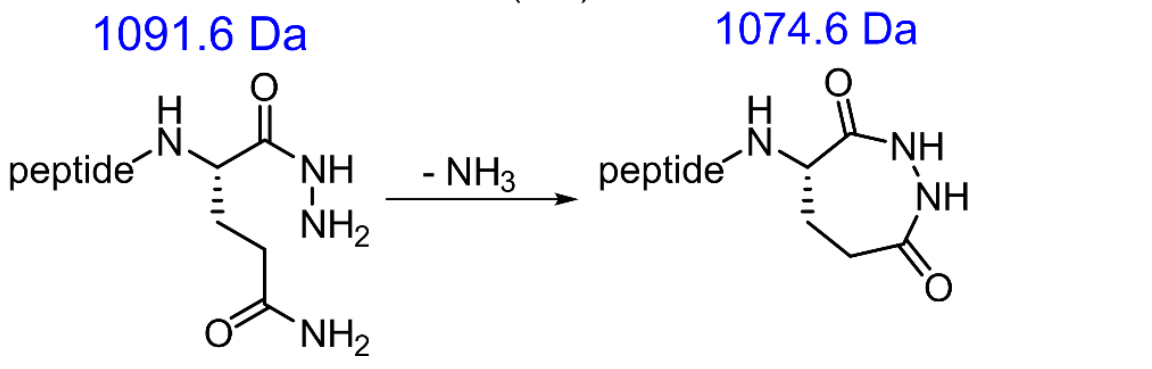


Figure S19. a) HPLC-MS (TIC) chromatograms obtained 12 hours apart from one HPLC fraction from the attempted purification of $\mathrm{H}_{2} \mathrm{~N}$-Ala-Ile-Val-Ile-Asn-Thr-Phe-Asp-Gly-Gln-CONHNH 2 The amount of undesired cyclization product, corresponding to peak 2, increased significantly during this time. b) The reported explanation for the formation of the observed -17 Da product: cyclization with the Gln side chain.

\subsection{0. $\mathrm{H}_{2} \mathrm{~N}-$ Gly-Gly-Gly-Gly-Gly-Leu-Glu-Ile-CONHNH${ }_{2}$}

The peptide was synthesized as described above (Section 2) on $215 \mathrm{mg}$ of resin. Following TFA cleavage the crude was redissolved in $99 \% \mathrm{~A} / 1 \% \mathrm{~B}$, and the resin was filtered out. The peptide was purified on the Waters system described in section 2.3 using the following gradient: $1 \% \mathrm{~B}$ in A for 5 minutes, then 1\%-31\% B ramping linearly over 90 minutes. Purification of crude peptide yielded $3.8 \mathrm{mg}$ of pure peptide after lyophilization.

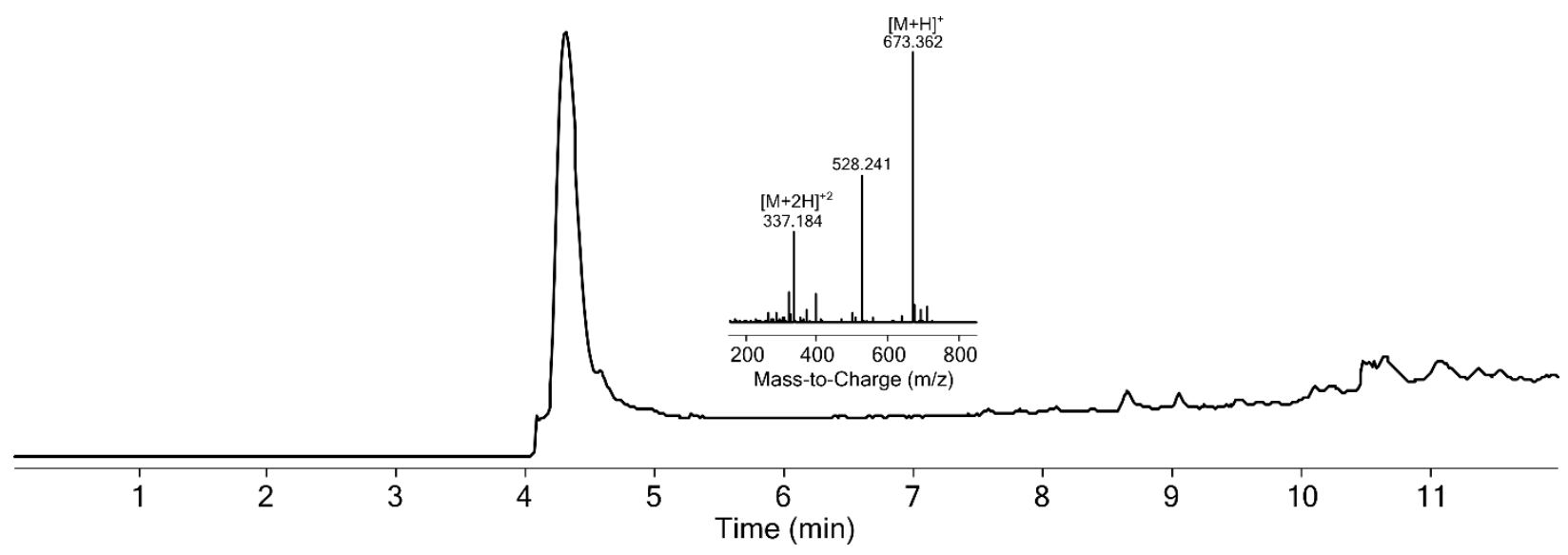

Figure S20. HPLC-MS (TIC) chromatogram for crude $\mathrm{H}_{2} \mathrm{~N}-\mathrm{Gly} 5$-Leu-Glu-Ile-CONHNH 2 with MS inset on the right. Calc. monoisotopic mass $=672.4$ Da.

\section{Additional experimental data}

\subsection{Discovery of isocyanate generation}

Some data shown in this section are a more detailed reproduction of the data mentioned in Mong, Vinogradov et al, ChemBioChem, 2014, 15, 721-733 describing the total synthesis of barnase. Originally, during oxidation/thioesterefication of barnase fragments, we consistently observed formation of MPAA thioester, contaminated with a side-product 15.0 Da more massive than thioester. It was observed for two different fragments.

In particular, during these studies we adhered to the standard oxidation/thioesterefication protocol described by Fang, Li et al. (Angew. Chem. Int. Ed. 2011, 50, 7645 -7649). Thus, 2.00 
mg (1.47 $\mu \mathrm{mol})$ of $\mathrm{H}_{2} \mathrm{~N}-\mathrm{Gly}_{5}-\mathrm{Ala}-\mathrm{Gln}$-Val-Ile-Asn-Thr-Phe-Asp-Gly-Val-CONHNH${ }_{2}$ were dissolved in $0.48 \mathrm{~mL}$ of oxidation buffer $\left(200 \mathrm{mM} \mathrm{Na}_{2} \mathrm{HPO}_{4}\right.$ and $6 \mathrm{M} \mathrm{Gn} \cdot \mathrm{HCl}$ in water, $\mathrm{pH}$ 3.2). The solution was incubated in an ice-salt bath at $-18^{\circ} \mathrm{C}$ for $10 \mathrm{~min}$ and then $48 \mu \mathrm{L}$ of $200 \mathrm{mM}$ $\mathrm{NaNO}_{2}$ solution in water was added to it dropwise while stirring. After $20 \mathrm{~min}$ an analytical sample for LC-MS was taken (Fig. S21) and then $0.48 \mathrm{~mL}$ of $0.2 \mathrm{M}$ MPAA in ligation buffer (200 $\mathrm{mM} \mathrm{Na} \mathrm{HPO}_{4}$ and $6 \mathrm{M} \mathrm{Gn} \cdot \mathrm{HCl}$ in water, $\mathrm{pH}$ 6.8) were added to the reaction. Upon complete addition of the MPAA solution, another analytical sample for the LC-MS was taken (Fig. S22).

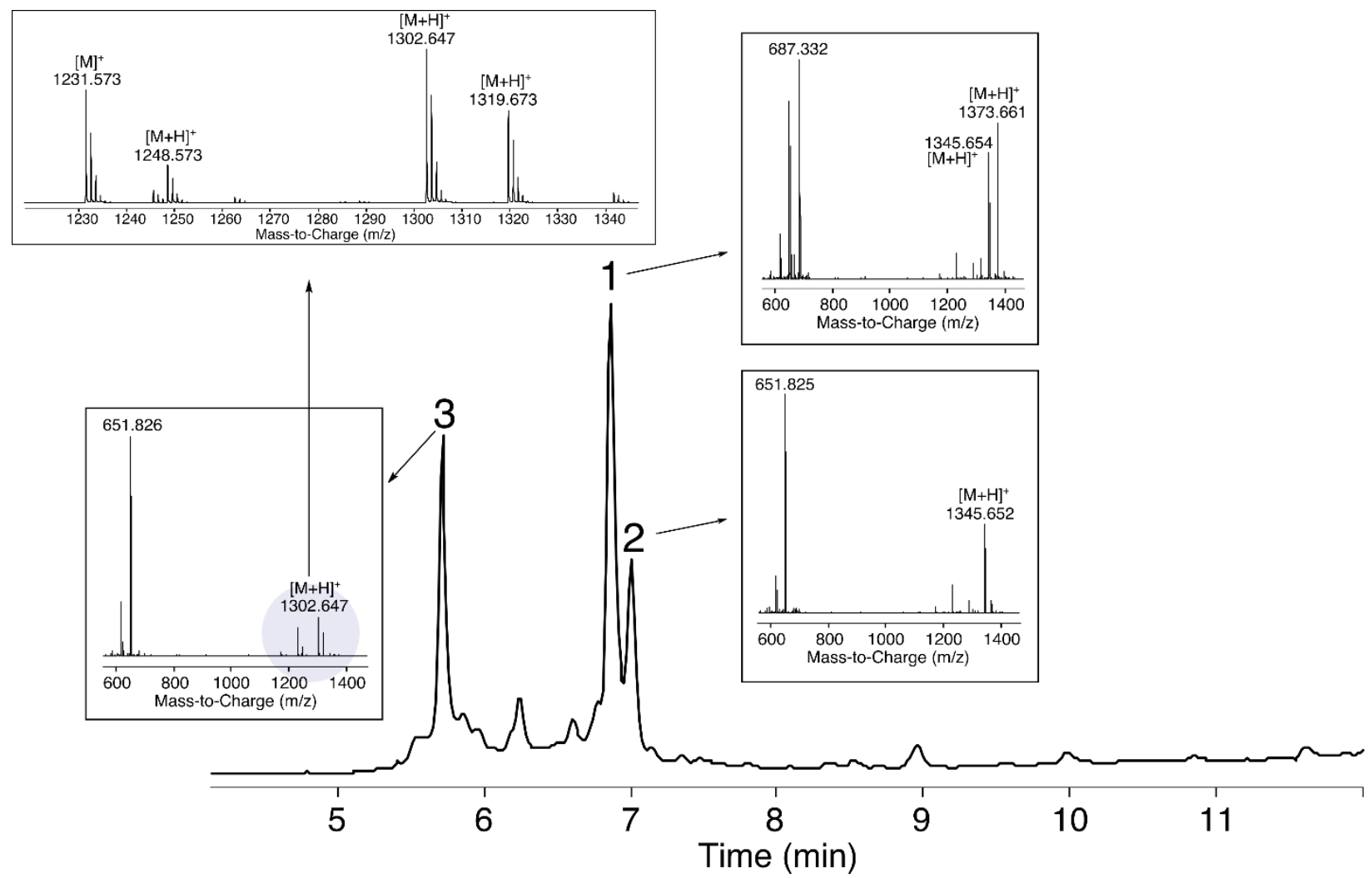

Figure S21 HPLC-MS (TIC) chromatogram for Gly5-Ala-Gln-Val-Ile-Asn-Thr-Phe-Asp-Gly-Val-CONHNH2 oxidation reaction with MS insets for main products. Peak 1 corresponds to the expected acyl azide product (calc. monoisotopic mass $=1372.7 \mathrm{Da}$ ). The chromatogram shows the formation of isocyanate (peak 2 with MS inset of the peak apex on the bottom right) during hydrazide oxidation in the studied system. Peak 3 with MS insets on the left corresponds to isocyanates hydrolysis products.

The data presented in Fig. S21 suggest that the hydrazide is successfully oxidized to form the acyl azide (peak 1). Two sets of ions (one is -28 Da relative to another) for peak 1 may be explained by the fragmentation of azide in the mass spectrum. Indeed, this behavior is quite common for azides (Li, Hoskins et al. Macromolecules, 2010, 43, 6225-6228). In contrast, peak $\mathbf{2}$ is chromatographically resolved from the azide peak and there is no parent azide ion, which 
allowed us to conclude that peak 2 is a real compound $28 \mathrm{Da}$ less massive than the azide. The mass difference of $28 \mathrm{Da}$ corresponds to a loss of a nitrogen molecule, which is consistent with the hypothesis that the acyl azide undergoes a Curtius rearrangement to release nitrogen and form an isocyanate. Analysis of peak $\mathbf{3}$ further supports this conclusion. The four major ions observed in the MS of the apex of peak $\mathbf{3}$ are consistent with isocyanate hydrolysis, which may be explained by the degradation of the C-terminal amino acid, which is accompanied by many intermediates, most of which can be observed in the MS (Scheme S1).

Scheme S1. Transformations of the C-terminal isocyanate in water.

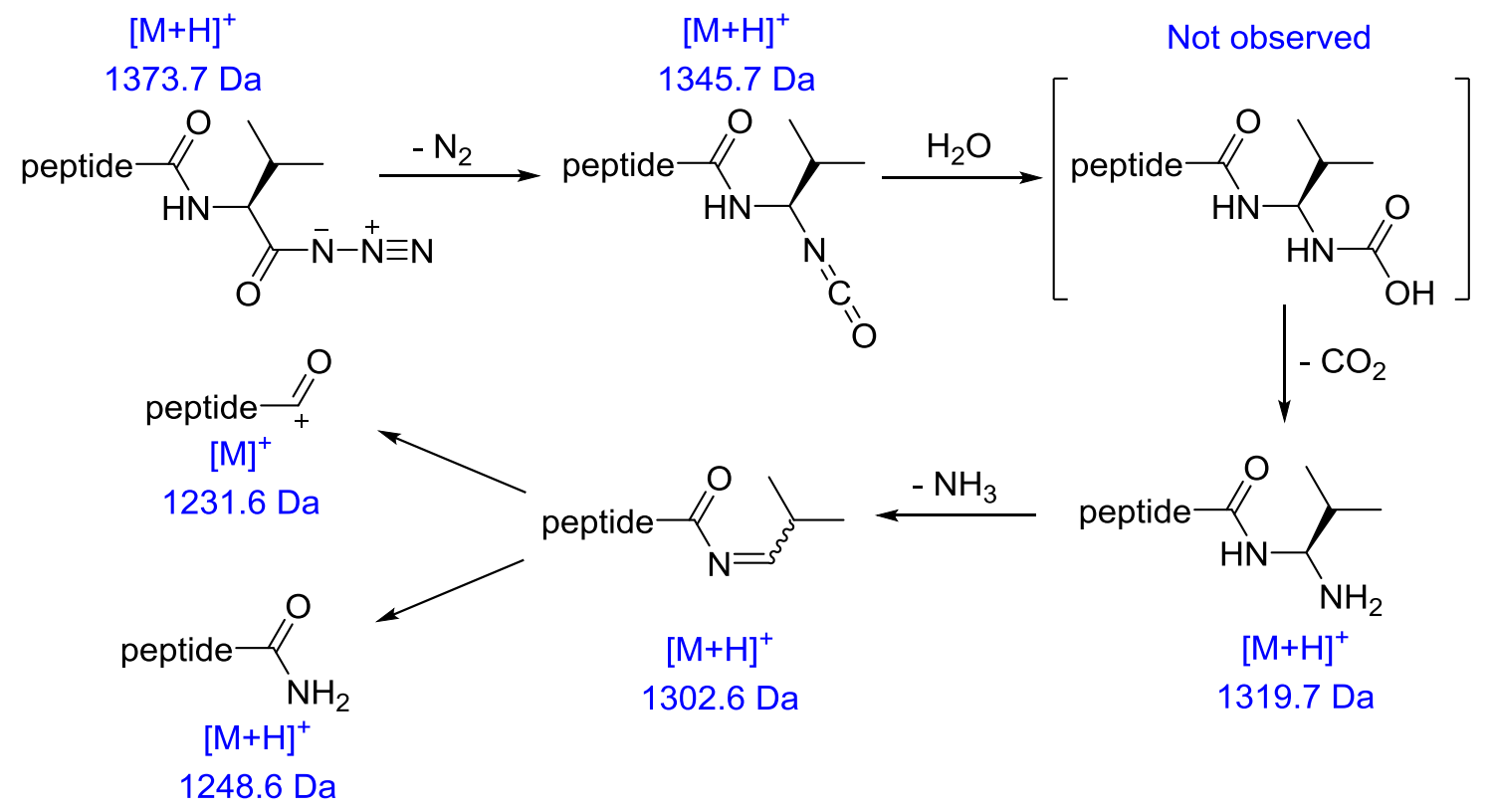

We observed similar ions series for most peptides in this study. Because in most cases we observed several products stemming from isocyanate hydrolysis, we refer to them collectively as 'isocyanate hydrolysis products' in the manuscript.

Figure $S 22$ shows the crude reaction mixture after addition of MPAA. Formation of peak 2 (+15 Da relative to the expected thioester) is consistent with the hypothesis that the acyl azide rearranges to isocyanate, because isocyanate may react with MPAA to give carbamothioate, which is 15 Da heavier than thioester (Scheme S2). 


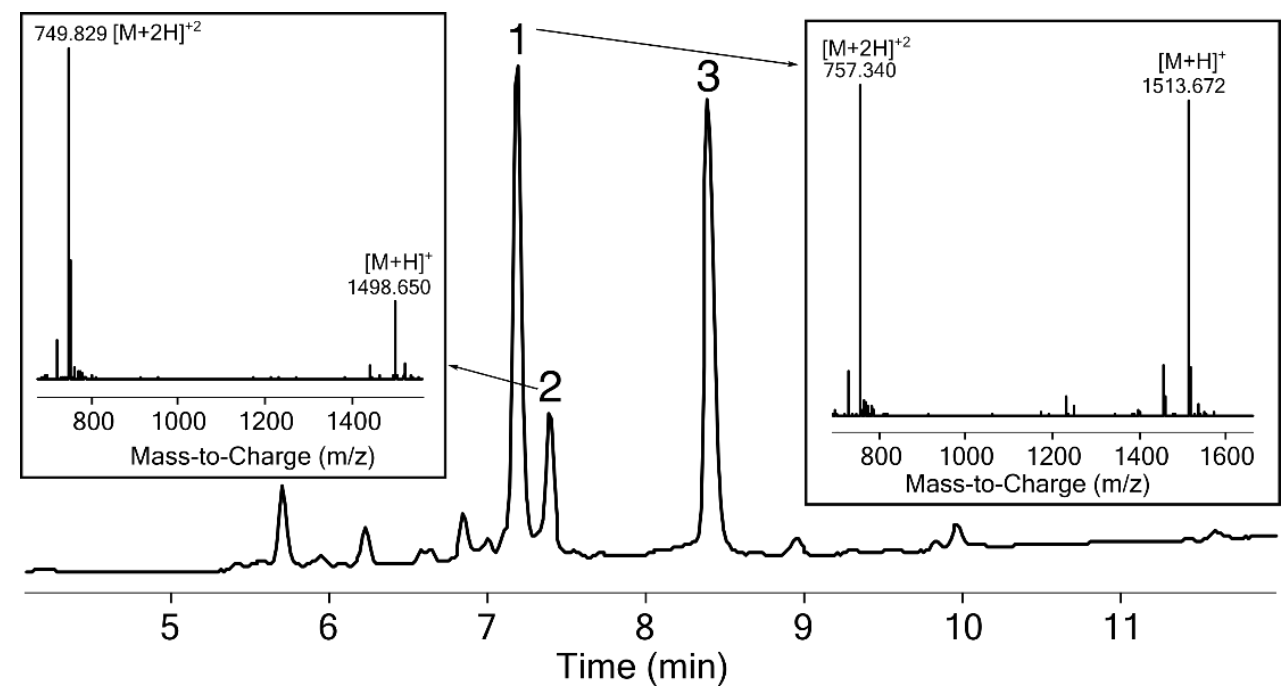

Figure S22: HPLC-MS (TIC) chromatogram for Gly5-Ala-Gln-Val-Ile-Asn-Thr-Phe-Asp-Gly-Val-CONHNH 2 oxidation/transesterification reaction with MS insets for main products. Peak 2 corresponds to the expected thioester product (calc. monoisotopic mass $=1498.6 \mathrm{Da}$ ). Peak 1 is the unexpected carbamothioate formed from the corresponding isocyanate. Peak 3 is MPAA disulfide.

Scheme S2. Chemical structures of C-terminal thioesters and carbamothioates: main products observed during thioesterefication of Gly5-Ala-Gln-Val-Ile-Asn-Thr-Phe-Asp-Gly-Val-CONHNH2.

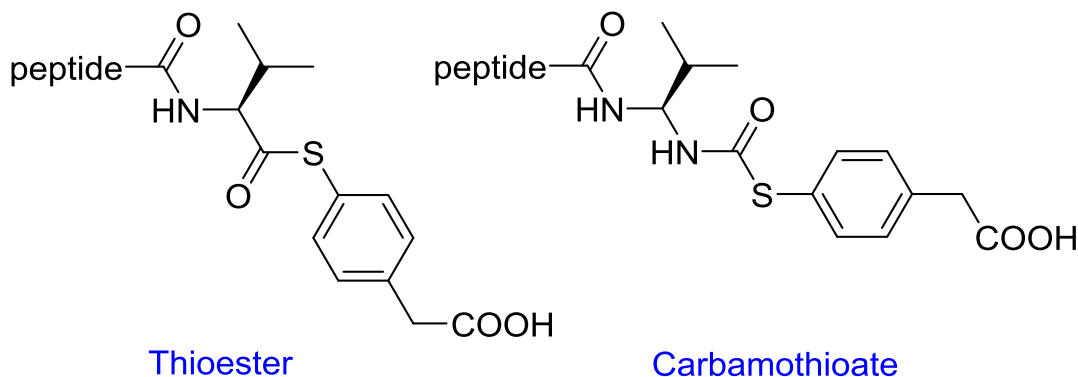

To exclude the possibility of side chains reacting with sodium nitrite or MPAA, we prepared the peptide $\mathrm{H}_{2} \mathrm{~N}-\mathrm{Gly}_{5}$-Ala-Gln-Val-Ile-Asn-Thr-Phe-Asp-Val-COOH and subjected it to the reaction conditions described above. The peptide was unreactive under these conditions, suggesting that the +15 Da product indeed stems from the C-terminal hydrazide oxidation.

Finally, we confirmed the structure of the conjugation product using MS/MS analysis. To this end, we performed oxidation/conjugation of a model peptide $\mathrm{H}_{2} \mathrm{~N}$-Ala-Arg-Val-Ile-Asn-ThrPhe-Asp-Gly-Tyr-CONHNH 2 under standard conditions (section 5.3) with $15 \mathrm{mM}$ perfluorophenylhydrazine as a nucleophile at $57{ }^{\circ} \mathrm{C}$. HPLC-MS chromatogram for the crude reaction mixture shown in Figure S23 confirmed that the nucleophile was conjugated to the peptide. We then performed the secondary MS analysis of the main product $[\mathrm{M}+\mathrm{H}]^{+}$and 
$[\mathrm{M}+2 \mathrm{H}]^{+2}$ ions. As Figure S24 shows, the fragmentation patterns of both ions match the expected structure well. These data unambiguously indicate that perfluorophenylhydrazine conjugated to the C-terminus of the peptide. More importantly, we observed the extensive fragmentation of the C-terminal moiety, which confirmed the presence of the semicarbazide functional group. Thus, we concluded that C-terminal acyl azides rearrange to isocyanates, which react with external nucleophiles to give conjugation products.

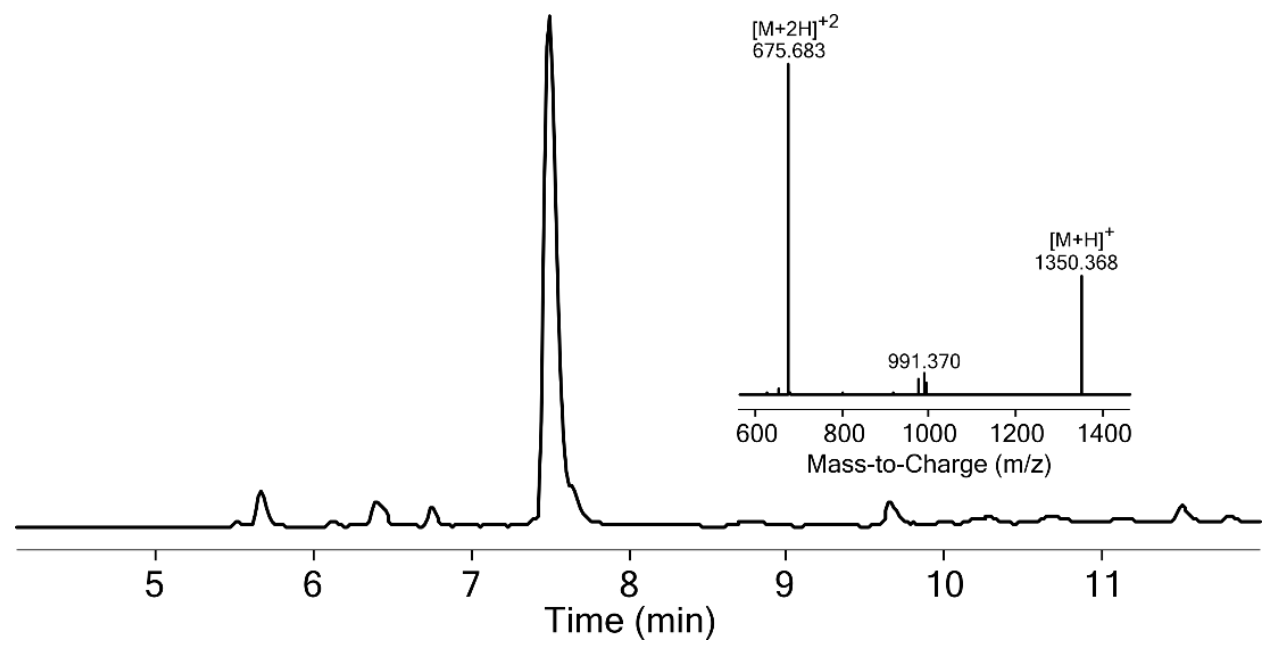

Figure S23. HPLC-MS (TIC) chromatogram for Ala-Arg-Val-Ile-Asn-Thr-Phe-Asp-Gly-Tyr-CONHNH ${ }_{2}$ oxidation/conjugation reaction with perfluorophenylhydrazine (MS inset for the main peak apex is on the right; calc. monoisotopic mass of the expected semicarbazide ion is $1350.6 \mathrm{Da})$ 
a)

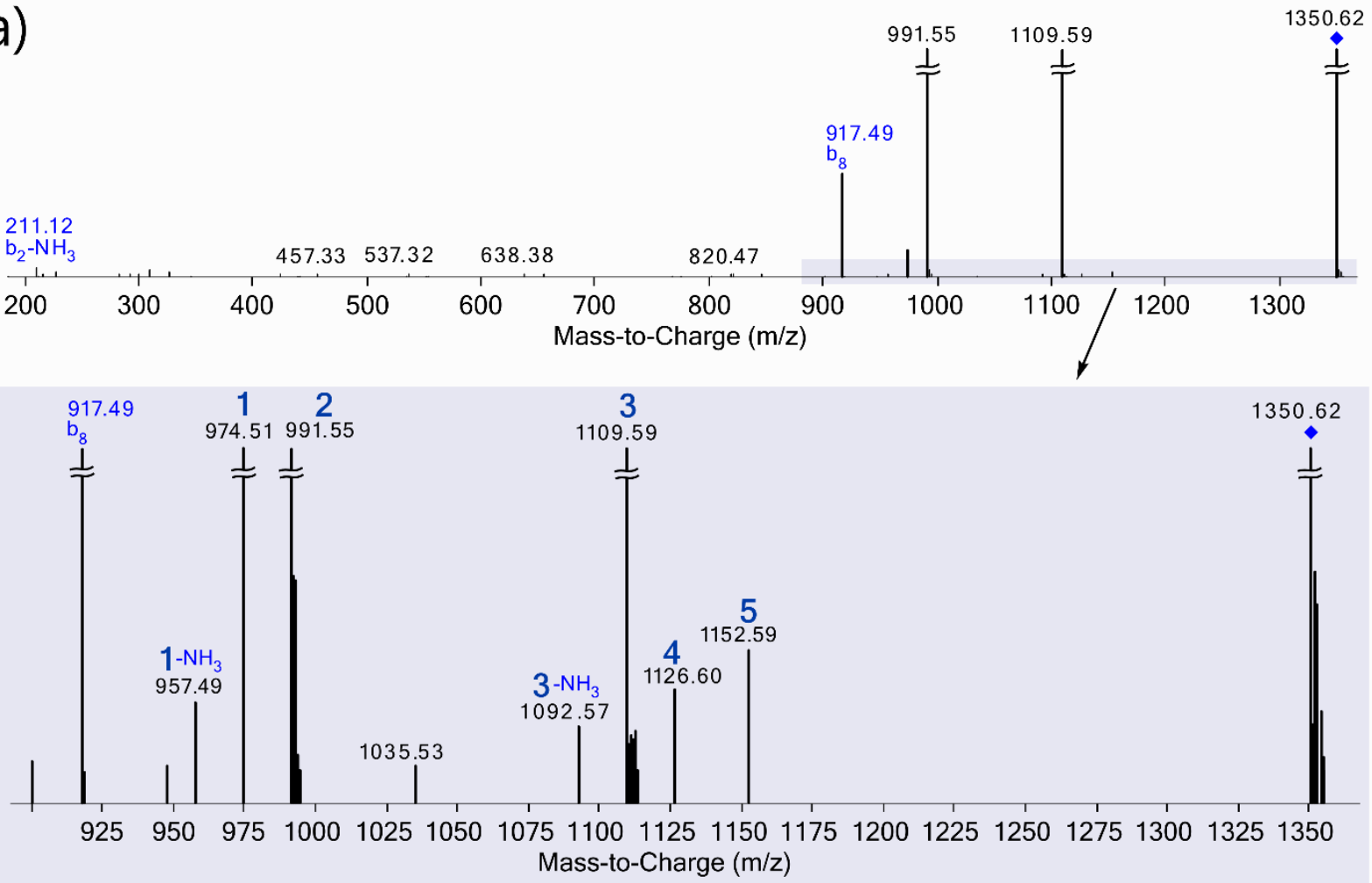

b) $\stackrel{136.08}{\perp}$

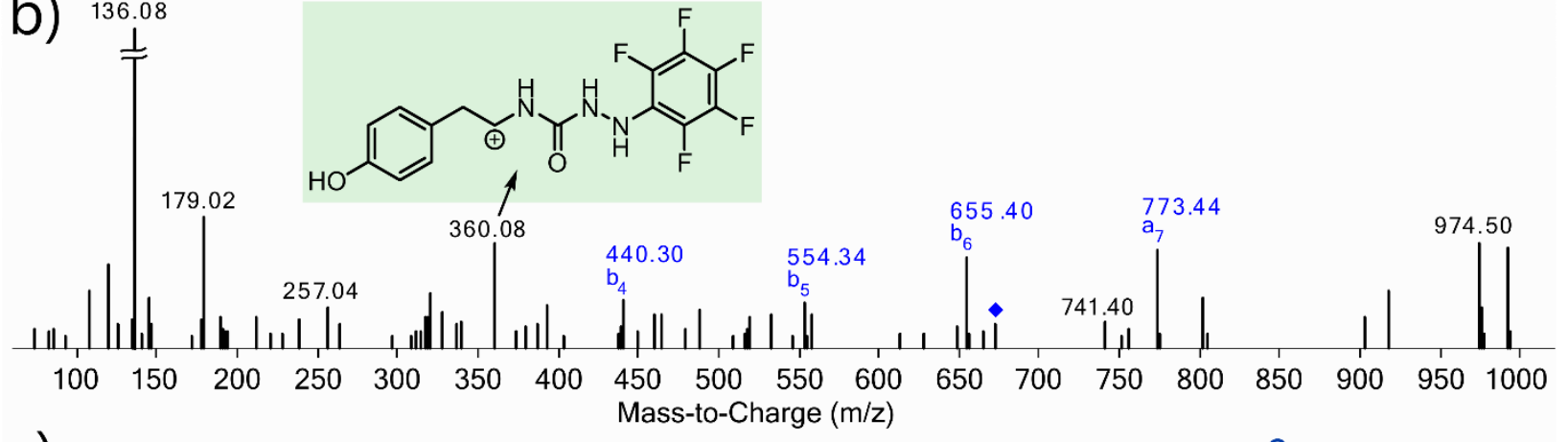

C)<smiles>CC[C@H](C)[C@H](NC(=O)[C@@H](NC(=O)[C@H](CCCNC(=N)N)NC(=O)[C@H](C)N)C(C)C)C(=O)N[C@@H](CC(N)=O)C(=O)N[C@H](C(=O)N[C@@H](Cc1ccccc1)C(=O)N[C@@H](CC(=O)O)C(=O)NCC(=O)NCCc1ccc(O)cc1)C(C)O</smiles>

Figure S24. a) Top: MS/MS chromatogram for $[\mathrm{M}+\mathrm{H}]^{+}$ion of the conjugation product. The parent ion is labelled as diamond. Bottom: zoom-in of the $900-1350 \mathrm{~m} / \mathrm{z}$ region of the spectrum on the top. Peak labels correspond to fragments shown in panel c). b) MS/MS chromatogram for $[\mathrm{M}+2 \mathrm{H}]^{+2}$ ion of the conjugation product. The parent ion is labelled as diamond. Some $a_{n}$ and $b_{n}$ 
fragments are labelled. The C-terminal fragment containing semicarbazide was also identified and labelled. c) Structural formula of the conjugation product indicating the most important fragments.

\subsection{Optimization of conjugation conditions}

To optimize reaction conditions we chose $\mathrm{H}_{2} \mathrm{~N}$-Ala-Gln-Val-Ile-Asn-Thr-Phe-Asp-Gly-Val$\mathrm{CONHNH}_{2}$ as a model peptide and MPAA as a nucleophile. $4.14 \mathrm{mg}(3.85 \mu \mathrm{mol})$ of peptide hydrazide were dissolved in $1.25 \mathrm{~mL}$ of oxidation buffer $\left(200 \mathrm{mM} \mathrm{Na} 2 \mathrm{HPO}_{4}\right.$ and $6 \mathrm{M} \mathrm{Gn} \cdot \mathrm{HCl}$ in water, $\mathrm{pH}$ 3.2). The solution was incubated in an ice-salt bath at $-10{ }^{\circ} \mathrm{C}$ for $5 \mathrm{~min}$ and then 125 $\mu \mathrm{L}$ of $200 \mathrm{mM} \mathrm{NaNO}_{2}$ solution in water was added to it dropwise. After $10 \mathrm{~min}, 100 \mu$ l oxidized peptide solution was added to each of the following solutions:

a) $100 \mu \mathrm{l}$ of $200 \mathrm{mM}$ MPAA in $200 \mathrm{mM} \mathrm{Na} 2 \mathrm{HPO}_{4}, 6 \mathrm{M} \mathrm{Gn} \cdot \mathrm{HCl}$ buffer, $\mathrm{pH} 4.5$ (thioester control experiment).

b) $100 \mu \mathrm{l}$ of $200 \mathrm{mM}$ MPAA in $200 \mathrm{mM} \mathrm{Na} 2 \mathrm{HPO}_{4}, 6 \mathrm{M} \mathrm{Gn} \cdot \mathrm{HCl}$ buffer, pH 9.4.

c) $100 \mu \mathrm{l}$ of $200 \mathrm{mM}$ MPAA in $200 \mathrm{mM} \mathrm{Na} 2 \mathrm{HPO}_{4}, 6 \mathrm{M} \mathrm{Gn} \cdot \mathrm{HCl}$ buffer, $\mathrm{pH} 4.5 \mathrm{pH}$ of the resulting solution was immediately adjusted to 7.4.

d) $200 \mu \mathrm{l}$ of acetonitrile. After 5 minutes at $\mathrm{rt}, 100 \mu \mathrm{l}$ of $200 \mathrm{mM}$ MPAA in $200 \mathrm{mM}$ $\mathrm{Na}_{2} \mathrm{HPO}_{4}, 6 \mathrm{M} \mathrm{Gn} \cdot \mathrm{HCl}$ buffer, $\mathrm{pH} 4.5$ was added.

e) $300 \mu 1$ of $67 \mathrm{mM}$ MPAA in water/acn (1: 1, v/v) with $0.1 \%$ TFA added.

f) $100 \mu \mathrm{l}$ of $200 \mathrm{mM}$ MPAA in $200 \mathrm{mM} \mathrm{Na} 2 \mathrm{HPO}_{4}, 6 \mathrm{M} \mathrm{Gn} \cdot \mathrm{HCl}$ buffer, $\mathrm{pH} 4.5$. The resulting solution was then immediately added to $1.8 \mathrm{~mL}$ water/acn $(1: 1, \mathrm{v} / \mathrm{v})$ with $0.1 \%$ TFA (final $\mathrm{pH} \sim 3.0$ ).

In each case the reaction was allowed to proceed for 120 minutes before an HPLC-MS sample was taken. 


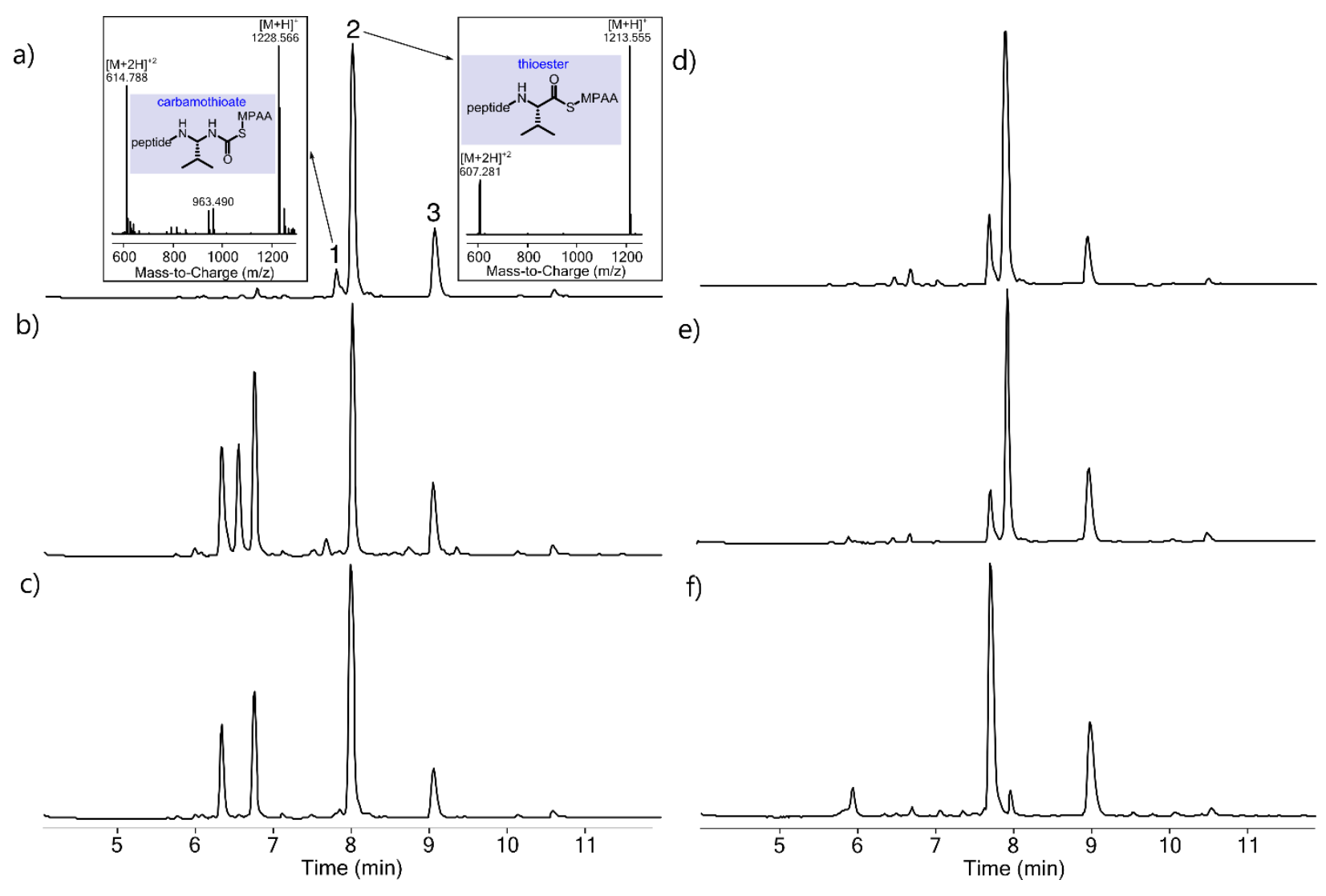

Figure S25. HPLC-MS (TIC) chromatograms for $\mathrm{H}_{2} \mathrm{~N}-\mathrm{Ala}-\mathrm{Gln}-\mathrm{Val}-\mathrm{Ile}-\mathrm{Asn}-\mathrm{Thr}-\mathrm{Phe}-\mathrm{Asp}-\mathrm{Gly}-\mathrm{Val}_{\mathrm{C}} \mathrm{CONHNH} \mathrm{H}_{2}$ oxidation/conjugation reaction with MS insets for main products. Peak 1 is the carbamothioate, Peak 2 is the thioester, and Peak 3 is MPAA disulfide. Chromatogram indices correspond to the reaction conditions specified above.

Data shown in Fig. S25 suggest that the exact order of reagent addition, pH of the reaction, or solvent composition had little influence on isocyanate generation. In fact, for reactions a) - e) we did not observe the formation of carbamothioate or other isocyanate derived products to any significant extent. In contrast, when we diluted both reagents (peptide to a final concentration of $133 \mu \mathrm{M}$, and MPAA to $\sim 10 \mathrm{mM}$ ) we observed formation of carbamothioate as the primary reaction product.

To elucidate the solvent effects we then performed 3 more reactions. $0.65 \mathrm{mg}$ peptide was oxidized as above, and then $35 \mu$ of oxidized peptide solution was added to each of the following solutions:

a) $1.0 \mathrm{~mL} 8 \mathrm{mM}$ MPAA solution in water/acn (1: 1, v/v) with $0.1 \%$ TFA added.

b) $1.0 \mathrm{~mL} 8 \mathrm{mM}$ MPAA solution in water/acn (3: 1, v/v) with $0.1 \%$ TFA added.

c) $1.0 \mathrm{~mL} 8 \mathrm{mM}$ MPAA solution in water with $0.1 \%$ TFA added. 
In each case the reaction was allowed to proceed for 120 minutes before an HPLC-MS sample was taken (Fig. S26). We concluded that the concentration of acetonitrile in the solvent plays a minor role in the overall process and opted for water/acn $(1: 1, \mathrm{v} / \mathrm{v})$ as a universal solvent for further experiments.

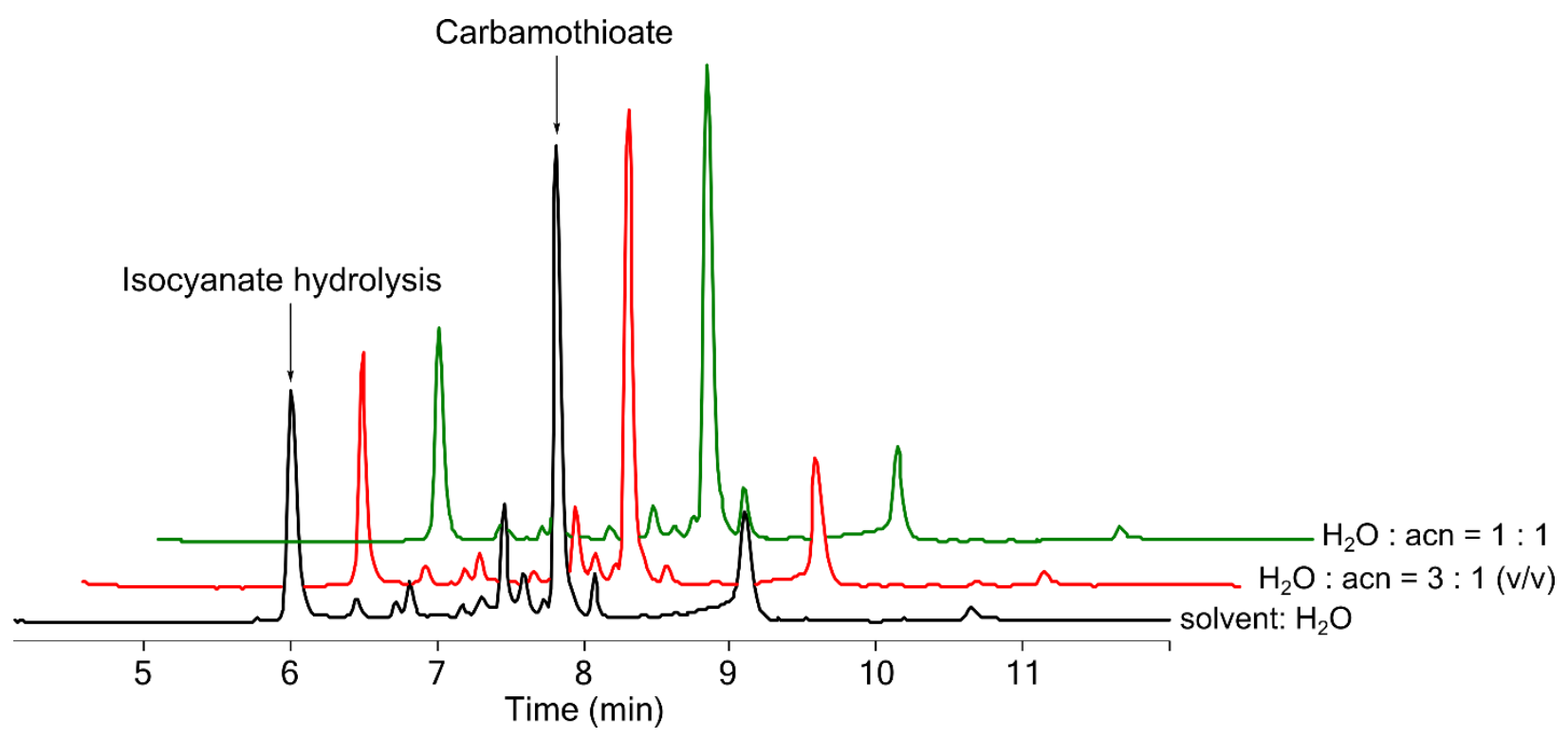

Figure S26. Overlaid HPLC-MS (TIC) chromatograms for $\mathrm{H}_{2} \mathrm{~N}-\mathrm{Ala}-\mathrm{Gln}-\mathrm{Val}-\mathrm{Ile}-\mathrm{Asn}-\mathrm{Thr}-\mathrm{Phe}-\mathrm{Asp}-\mathrm{Gly}-\mathrm{Val}-\mathrm{CONHNH} 2$ oxidation/conjugation reaction in different solvents. Although the cleanest product was obtained in water/acn $(1: 1, \mathrm{v} / \mathrm{v})$, the influence of acetonitrile concentration is minor.

\subsection{Standard reaction procedure for conjugation of nucleophiles to peptide isocyanates}

Unless noted, all isocyanate conjugations below are performed under the following standard conditions: $3.07 \mathrm{mM}$ peptide hydrazide solution in oxidation buffer $\left(200 \mathrm{mM} \mathrm{Na} \mathrm{HPO}_{4}\right.$ and $6 \mathrm{M}$ $\mathrm{Gn} \cdot \mathrm{HCl}$ in water, $\mathrm{pH} 3.2$ ) was incubated in an ice-salt bath at $-10{ }^{\circ} \mathrm{C}$ for $5 \mathrm{~min}$, and then 200 $m M \mathrm{NaNO}_{2}$ solution in water was carefully added to the peptide to a final $\mathrm{NaNO}_{2}$ concentration of $18 \mathrm{mM}$. The reaction was allowed to proceed for 10 minutes at $-10{ }^{\circ} \mathrm{C}$. Then, a solution of nucleophile in water/acetonitrile (1: 1 , v/v, $0.1 \%$ TFA added, $\mathrm{pH} \sim 3.0-4.5)$ was added to the reaction mixture to a final peptide concentration of $133 \mu \mathrm{M}$ and the mixture was warmed to the desired temperature (usually 17 or $57^{\circ} \mathrm{C}$ ). Depending on the temperature, the reaction mixture was analyzed using HPLC-MS after 20 minutes $\left(57^{\circ} \mathrm{C}\right.$ reaction) or 120 minutes $\left(17^{\circ} \mathrm{C}\right.$ reaction). 


\subsection{Nucleophile scope of the reaction}

For this study the reactions were carried out following the standard conditions at $60{ }^{\circ} \mathrm{C}$ for 20 minutes except water/acetonitrile $(1: 3, \mathrm{v} / \mathrm{v})$ was used as a solvent for the conjugation step. Following the reaction, the solutions were further acidified with citric acid monohydrate to its final concentration of $150 \mathrm{mM}$ and cooled down to room temperature. The excess of acetonitrile was removed in vacuo; the remaining reaction mixtures were diluted into $95 \% \mathrm{~A} / 5 \% \mathrm{~B}$ and purified by RP-HPLC as described in section 2.3.

\subsection{1. $\mathrm{H}_{2} \mathrm{~N}$-Ala-Gln-Val-Ile-Asn-Thr-Phe-Asp-Gly-Val-CONHNH ${ }_{2}+$ Perfluorophenyl- hydrazine}

$4.8 \mathrm{mg}$ peptide was dissolved in $1.45 \mathrm{~mL}$ oxidation buffer, oxidized with $145 \mu \mathrm{L}$ of $200 \mathrm{mM}$ $\mathrm{NaNO}_{2}$, and diluted into $33 \mathrm{~mL}$ of $25 \mathrm{mM}$ perfluorophenylhydrazine in water/acetonitrile (1: 3 , $\mathrm{v} / \mathrm{v})$. After $1.04 \mathrm{~g}$ of citric acid was added to the reaction mixture, the excess of acetonitrile was evaporated and the remaining solution $(\sim 10 \mathrm{~mL})$ was diluted with $95 \% \mathrm{~A} / 5 \% \mathrm{~B}$ to a total of 40 $\mathrm{mL}$. RP-HPLC purification followed by lyophilization yielded $4.6 \mathrm{mg}$ ( $82 \%$ yield) of the desired semicarbazide as a white powder (Fig. S27).

a)

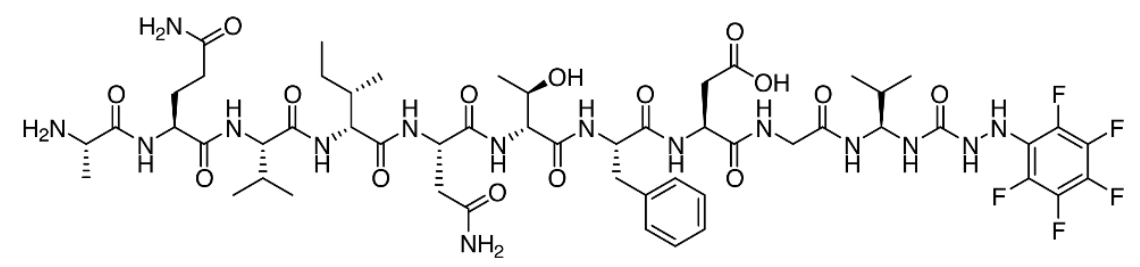

b)

c)

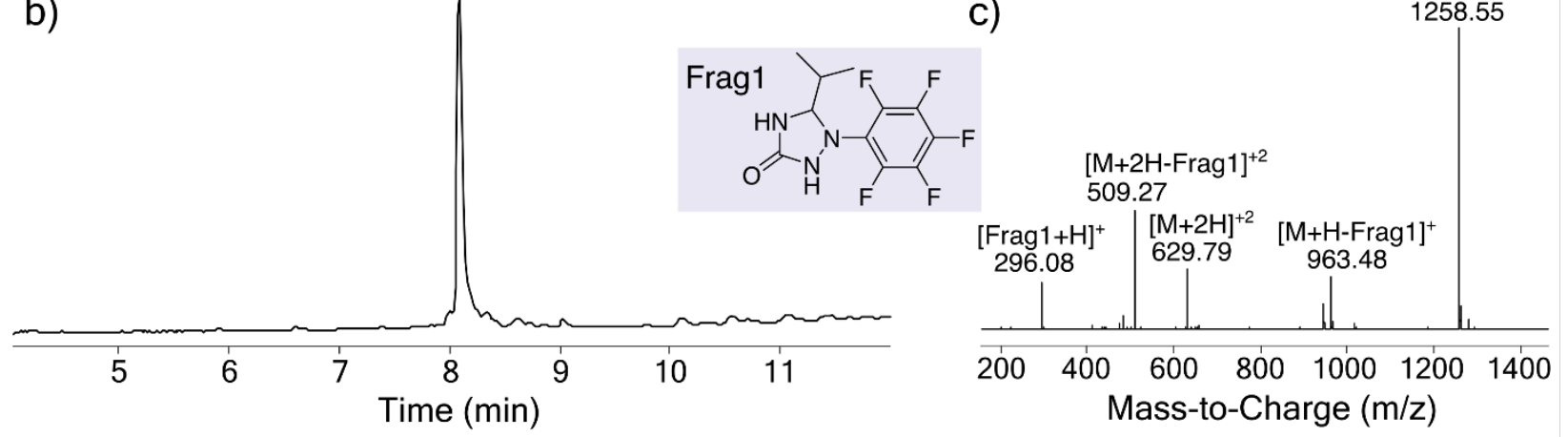

Figure S27. HPLC-MS (TIC) chromatogram (b) for the purified semicarbazide peptide $\mathrm{H}_{2} \mathrm{~N}-\mathrm{Ala}-\mathrm{Gln}$-Val-Ile-Asn-Thr-Phe-AspGly-Val-NH-CONHNH-C $\mathrm{C}_{6} \mathrm{~F}_{5}$ with the peptide structure shown in a). c) MS of the compound with major peaks assigned. ESIinduced peptide fragment Frag1 is postulated to exist in a cyclic form as drawn. Calc. monoisotopic mass $=1257.56 \mathrm{Da}$. 


\subsection{2. $\mathrm{H}_{2} \mathrm{~N}$-Ala-Gln-Val-Ile-Asn-Thr-Phe-Asp-Gly-Val-CONHNH $2+$ 2,4-dinitrophenyl- hydrazine}

$4.8 \mathrm{mg}$ peptide was dissolved in $1.45 \mathrm{~mL}$ oxidation buffer, oxidized with $145 \mu \mathrm{L}$ of $200 \mathrm{mM}$ $\mathrm{NaNO}_{2}$, and diluted into $33 \mathrm{~mL}$ of saturated solution of 2,4-dinitrophenylhydrazine in water/acetonitrile $(1: 3, \mathrm{v} / \mathrm{v})$. After $1.04 \mathrm{~g}$ of citric acid was added to the reaction mixture, the excess of acetonitrile was evaporated and the remaining solution $(\sim 10 \mathrm{~mL})$ was diluted with $95 \%$ $\mathrm{A} / 5 \% \mathrm{~B}$ to a total of $40 \mathrm{~mL}$. RP-HPLC purification followed by lyophilization yielded $2.7 \mathrm{mg}$ (48\% yield) of the desired semicarbazide as an ochre powder (Fig. S28).

a)
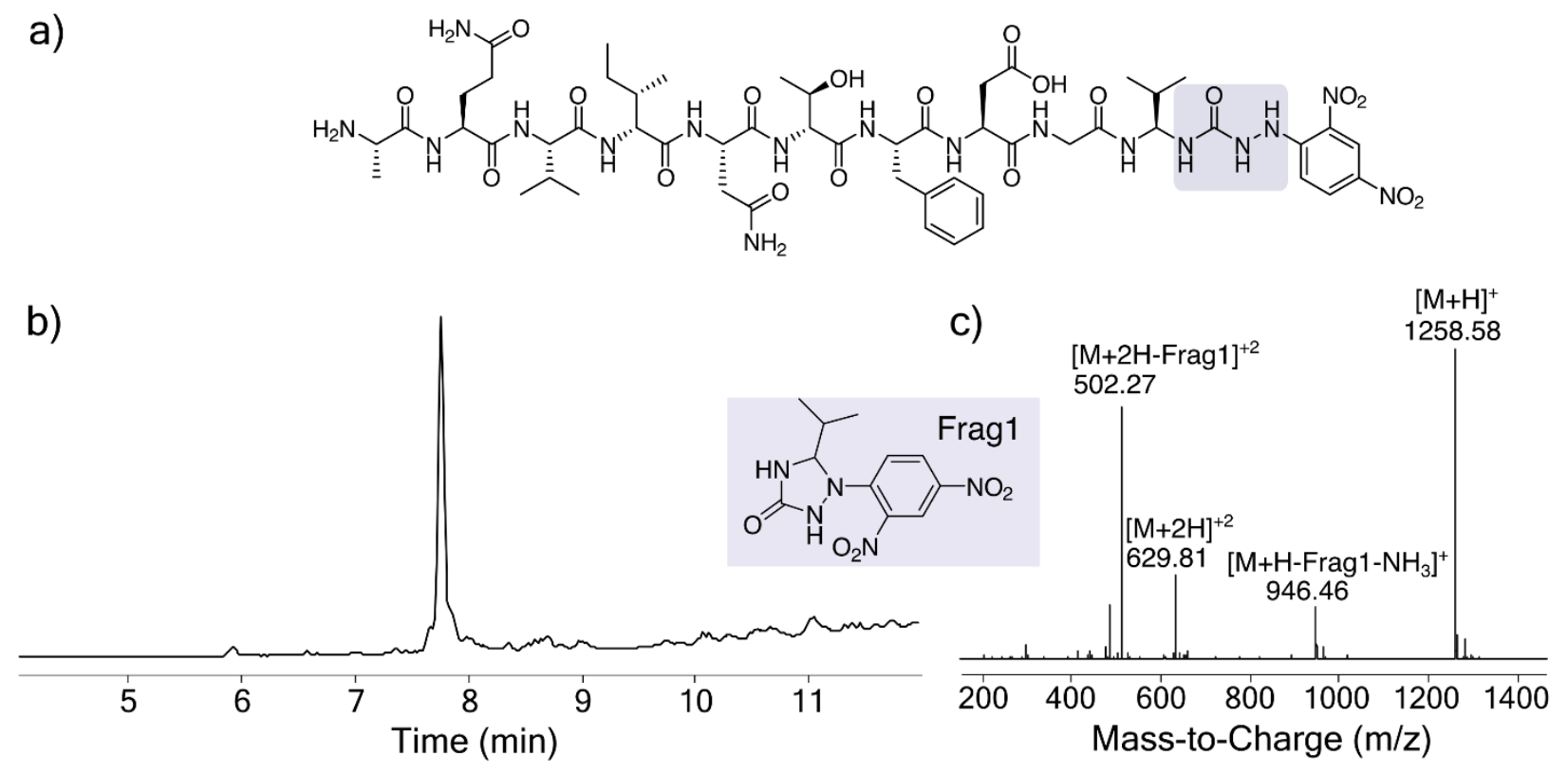

Figure S28. HPLC-MS (TIC) chromatogram (b) for the purified semicarbazide peptide $\mathrm{H}_{2} \mathrm{~N}-\mathrm{Ala}-\mathrm{Gln}$-Val-Ile-Asn-Thr-Phe-AspGly-Val-NH-CONHNH- $\mathrm{C}_{6} \mathrm{H}_{4}-\left(\mathrm{NO}_{2}\right)_{2}$ with the peptide structure shown in a). c) MS of the compound with major peaks assigned. ESI-induced peptide fragment Frag1 is postulated to exist in a cyclic form as drawn. Calc. monoisotopic mass $=1257.56$ Da.

\subsection{3. $\mathrm{H}_{2} \mathrm{~N}$-Ala-Gln-Val-Ile-Asn-Thr-Phe-Asp-Gly-Val-CONHNH${ }_{2}+$} 4-hydroxybenzhydrazide

$9.1 \mathrm{mg}$ peptide was dissolved in $2.75 \mathrm{~mL}$ oxidation buffer, oxidized with $275 \mu \mathrm{L}$ of $200 \mathrm{mM}$ $\mathrm{NaNO}_{2}$, and diluted into $64 \mathrm{~mL}$ of $30 \mathrm{mM}$ 4-hydroxybenzhydrazide in water/acetonitrile (1:3, $\mathrm{v} / \mathrm{v})$. After $1.89 \mathrm{~g}$ of citric acid was added to the reaction mixture, the excess of acetonitrile was evaporated and the remaining solution was diluted with $95 \% \mathrm{~A} / 5 \% \mathrm{~B}$ to a total of $40 \mathrm{~mL}$. RPHPLC purification followed by lyophilization yielded $7.5 \mathrm{mg}$ (73\% yield) of the desired N'-acylsemicarbazide as a white powder (Fig. S29). 


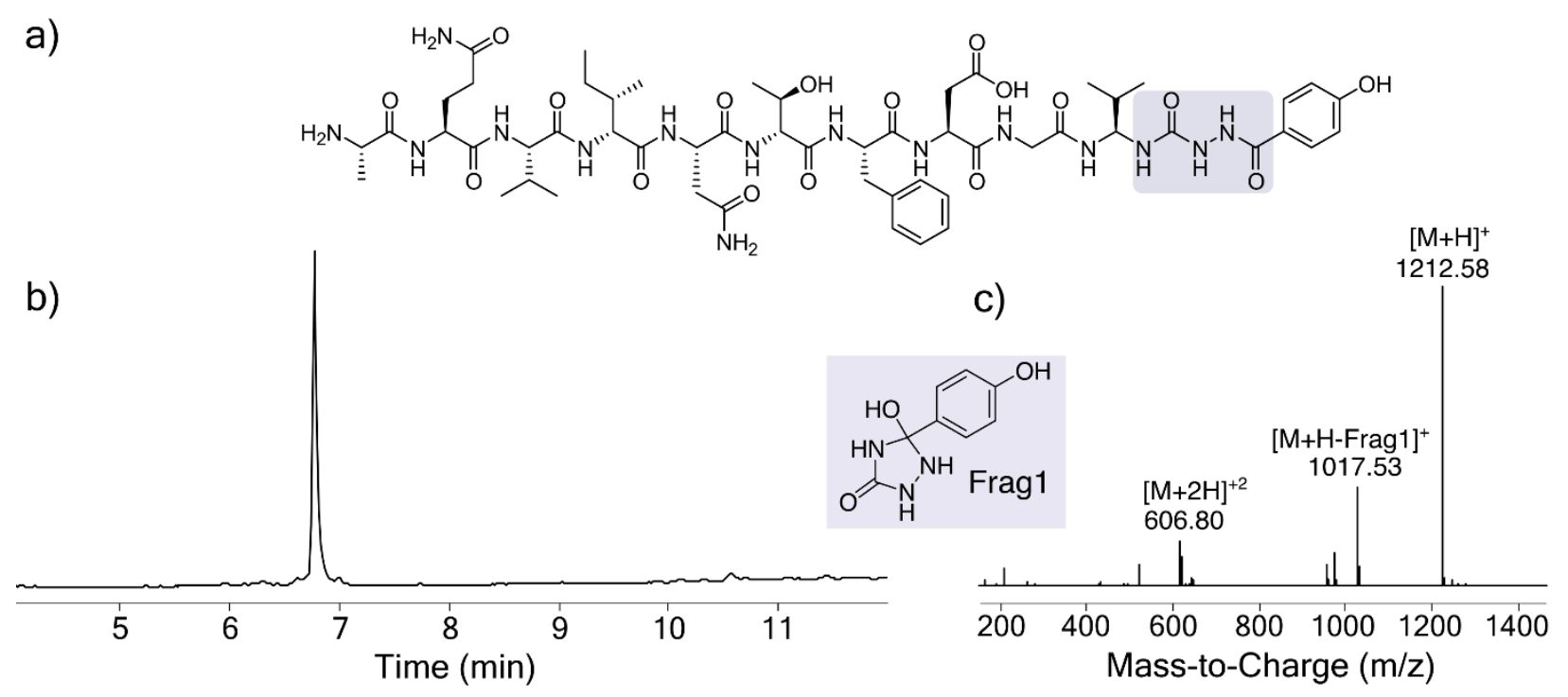

Figure S29. HPLC-MS (TIC) chromatogram (b) for the purified N'-acyl-semicarbazide peptide $\mathrm{H}_{2} \mathrm{~N}-\mathrm{Ala}-\mathrm{Gln}-\mathrm{Val}-\mathrm{Ile}-\mathrm{Asn}-\mathrm{Thr}-$ Phe-Asp-Gly-Val-NH-CONHNHCO-C $6 \mathrm{H}_{5}-\mathrm{OH}$ with the peptide structure shown in a). c) MS of the compound with major peaks assigned. ESI-induced peptide fragment Frag1 is postulated to exist in a cyclic form as drawn. Calc. monoisotopic mass = 1211.59 Da.

\subsection{4. $\mathrm{H}_{2} \mathrm{~N}$-Ala-Gln-Val-Ile-Asn-Thr-Phe-Asp-Gly-Val-CONHNH $\mathrm{H}_{2}+$ D-biotin hydrazide}

$3.1 \mathrm{mg}$ peptide was dissolved in $0.94 \mathrm{~mL}$ oxidation buffer, oxidized with $94 \mu \mathrm{L}$ of $200 \mathrm{mM}$ $\mathrm{NaNO}_{2}$, and diluted into $11.5 \mathrm{~mL}$ of $30 \mathrm{mM}$ D-biotin hydrazide in water/acetonitrile (1: 3, v/v). After $360 \mathrm{mg}$ of citric acid was added to the reaction mixture, the excess of acetonitrile was evaporated and the remaining solution was diluted with $95 \%$ A/5\% B to a total of $25 \mathrm{~mL}$. RPHPLC purification followed by lyophilization yielded $2.6 \mathrm{mg}$ (68\% yield) of the desired N'-acylsemicarbazide as a white powder (Fig. S30). 


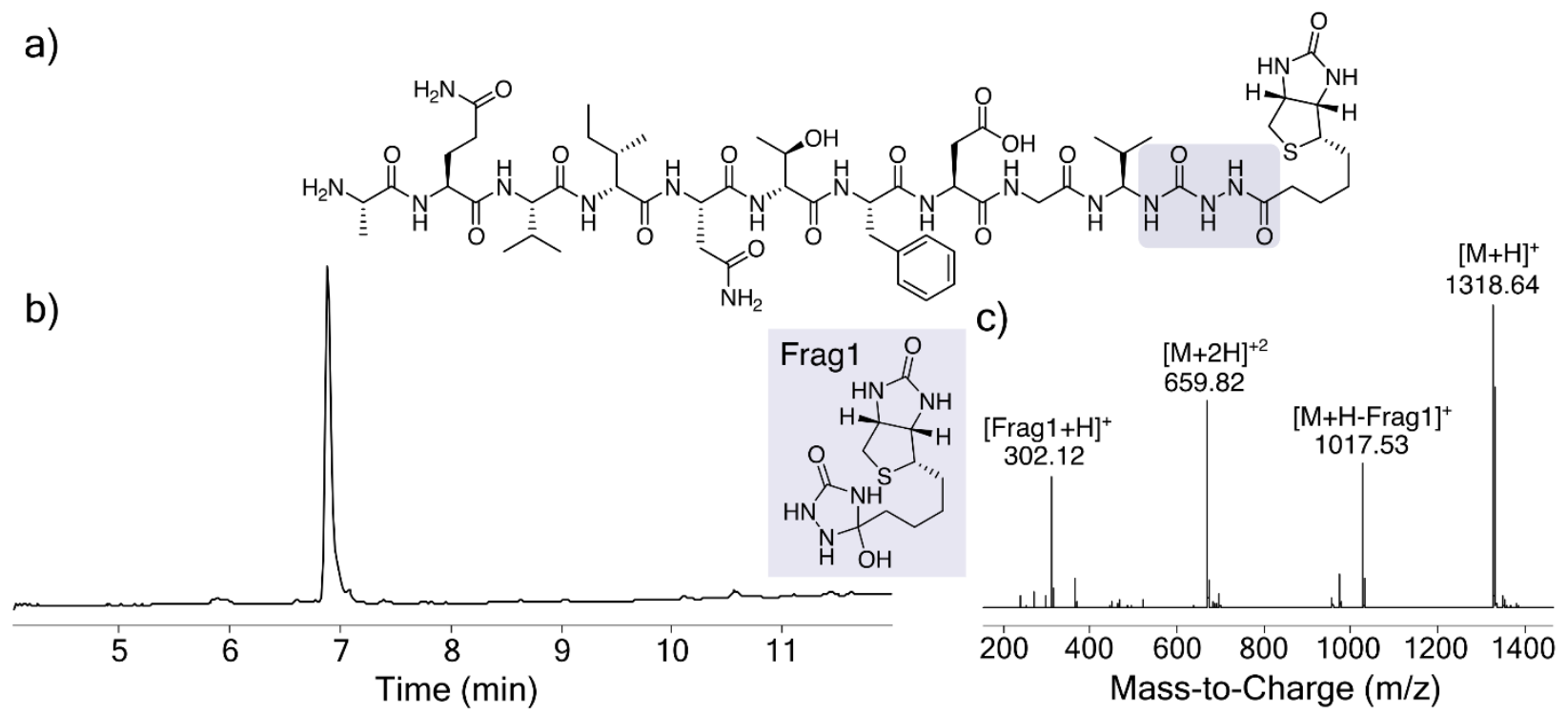

Figure S30. HPLC-MS (TIC) chromatogram (b) for the purified N'-acyl-semicarbazide peptide $\mathrm{H}_{2} \mathrm{~N}-\mathrm{Ala}-\mathrm{Gln}$-Val-Ile-Asn-ThrPhe-Asp-Gly-Val-NH-CONHNHCO-biotin with the peptide structure shown in a). c) MS of the compound with major peaks assigned. ESI-induced peptide fragment Frag1 is postulated to exist in a cyclic form as drawn. Calc. monoisotopic mass $=$ 1317.65 Da.

\subsection{5. $\mathrm{H}_{2} \mathrm{~N}-\mathrm{Ala}-\mathrm{Gln}-$ Val-Ile-Asn-Thr-Phe-Asp-Gly-Val-CONHNH $2+\mathrm{O}-(2,3,4,5,6-$ pentafluorobenzyl)-hydroxylamine}

$9.0 \mathrm{mg}$ peptide was dissolved in $2.72 \mathrm{~mL}$ oxidation buffer, oxidized with $272 \mu \mathrm{L}$ of $200 \mathrm{mM}$ $\mathrm{NaNO}_{2}$, and diluted into $63 \mathrm{~mL}$ of $100 \mathrm{mM} \mathrm{O}$-(2,3,4,5,6-pentafluorobenzyl)-hydroxylamine hydrochloride in water/acetonitrile (1:3, v/v) pHed to 3.1 with $5 \mathrm{M} \mathrm{NaOH}$ in water. After $1.89 \mathrm{~g}$ of citric acid was added to the reaction mixture, the excess of acetonitrile was evaporated and the remaining solution $(\sim 15 \mathrm{~mL})$ was diluted with $95 \% \mathrm{~A} / 5 \%$ B to a total of $40 \mathrm{~mL}$. RP-HPLC purification followed by lyophilization yielded $5.6 \mathrm{mg}$ (53\% yield) of the desired hydroxyurea derivative as a white powder (Fig. S31). 
a)

b)

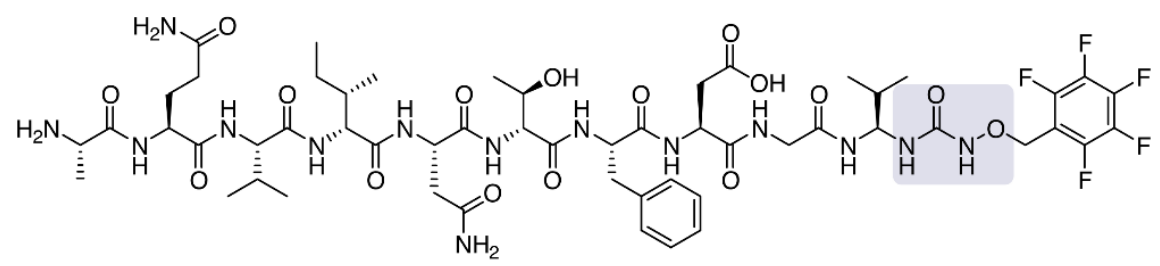

c)

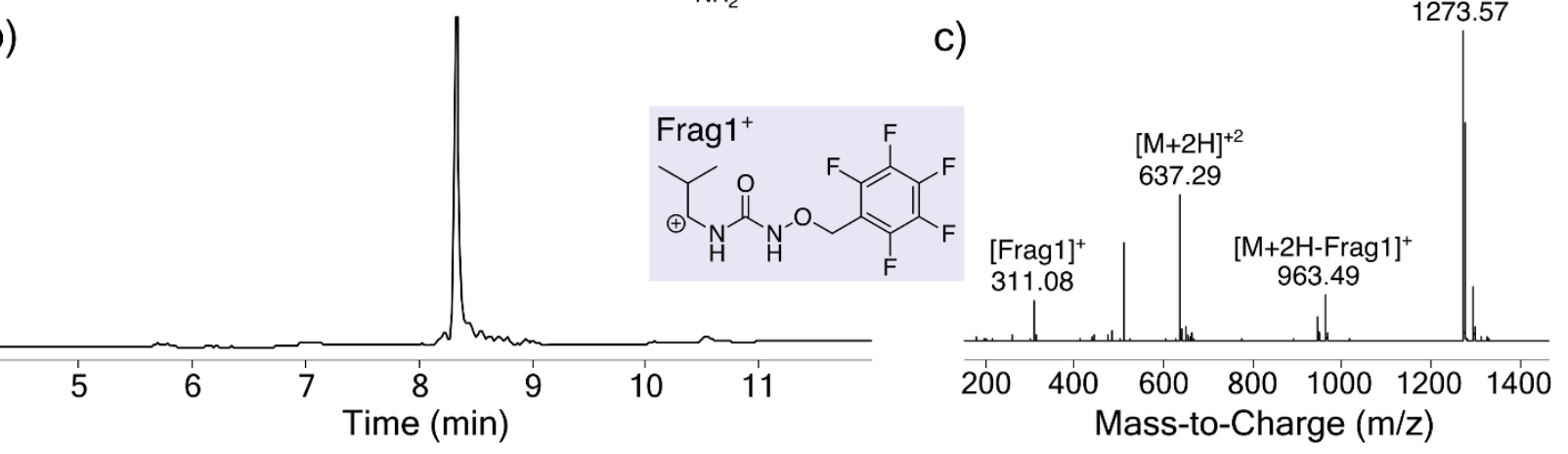

Figure S31. HPLC-MS (TIC) chromatogram (b) for the purified hydroxyurea derivative peptide $\mathrm{H}_{2} \mathrm{~N}-\mathrm{Ala}-\mathrm{Gln}-\mathrm{Val}-\mathrm{Ile}-\mathrm{Asn}-\mathrm{Thr}-$ Phe-Asp-Gly-Val-NH-CONHO- $\mathrm{CH}_{2}-\mathrm{C}_{6} \mathrm{~F}_{5}$ with the peptide structure shown in a). c) MS of the compound with major peaks assigned. ESI-induced peptide fragment Frag1 is postulated to exist in a linear form as drawn. Calc. monoisotopic mass = 1272.56 Da.

\subsection{6. $\mathrm{H}_{2} \mathrm{~N}$-Ala-Gln-Val-Ile-Asn-Thr-Phe-Asp-Gly-Val-CONHNH $\mathrm{H}_{2}+$ methoxyamine}

$9.5 \mathrm{mg}$ peptide was dissolved in $2.87 \mathrm{~mL}$ oxidation buffer, oxidized with $287 \mu \mathrm{L}$ of $200 \mathrm{mM}$ $\mathrm{NaNO}_{2}$, and diluted into $67 \mathrm{~mL}$ of $100 \mathrm{mM}$ methoxyamine hydrochloride in water/acetonitrile (1: $3, \mathrm{v} / \mathrm{v}$ ) pHed to 3.1 with $5 \mathrm{M} \mathrm{NaOH}$ in water. After $2.0 \mathrm{~g}$ of citric acid was added to the reaction mixture, the excess of acetonitrile was evaporated and the remaining solution $(\sim 15 \mathrm{~mL})$ was diluted with $95 \% \mathrm{~A} / 5 \% \mathrm{~B}$ to a total of $40 \mathrm{~mL}$. RP-HPLC purification followed by lyophilization yielded $4.1 \mathrm{mg}$ ( $42 \%$ yield) of the desired hydroxyurea derivative as a white powder (Fig. S32). 


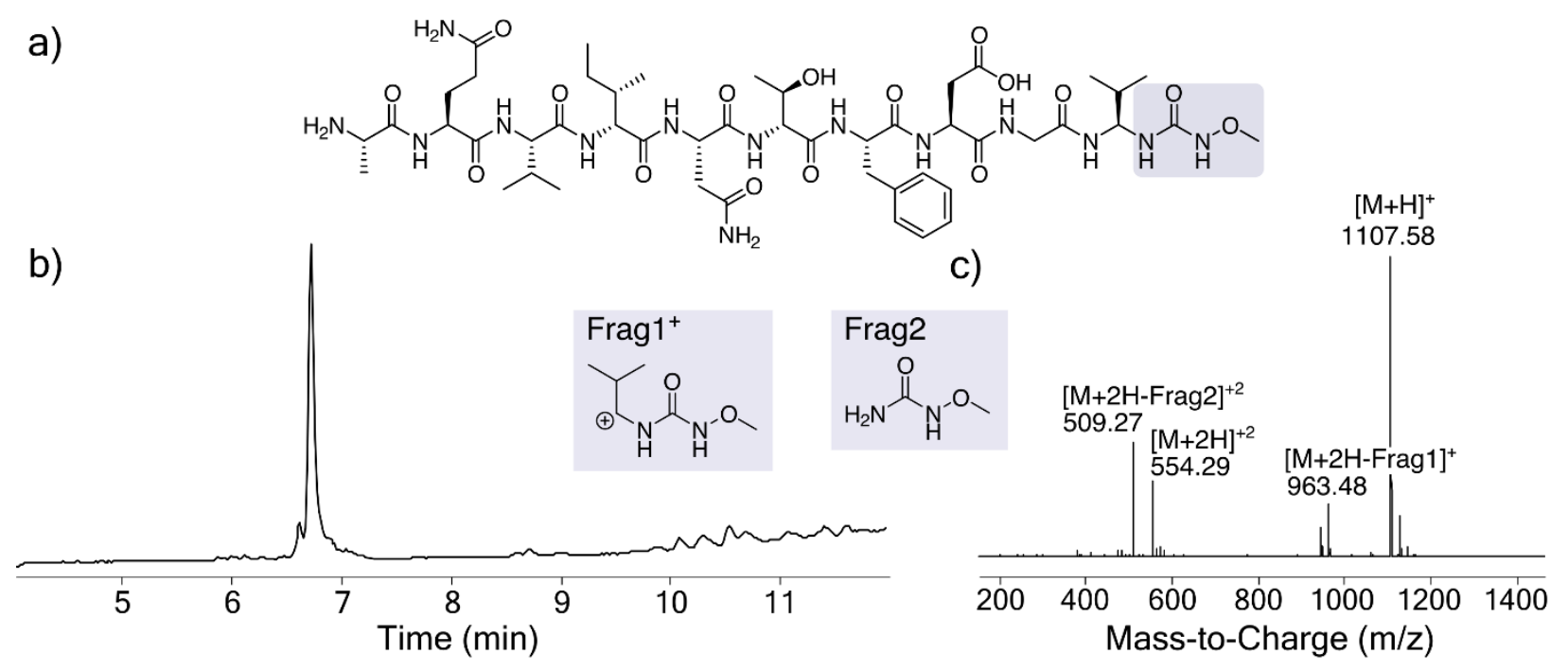

Figure S32. HPLC-MS (TIC) chromatogram (b) for the purified hydroxyurea derivative peptide $\mathrm{H}_{2} \mathrm{~N}-\mathrm{Ala}-\mathrm{Gln}-\mathrm{Val}-\mathrm{Ile}-\mathrm{Asn}-\mathrm{Thr}-$ Phe-Asp-Gly-Val-NH-CONHOCH 3 with the peptide structure shown in a). c) MS of the compound with major peaks assigned. ESI-induced peptide fragment Frag1 is postulated to exist in a linear form as drawn. Calc. monoisotopic mass $=1106.57$ Da.

\subsection{7. $\mathrm{H}_{2} \mathrm{~N}$-Ala-Gln-Val-Ile-Asn-Thr-Phe-Asp-Gly-Val-CONHNH ${ }_{2}+\mathrm{MPAA}$}

$9.5 \mathrm{mg}$ peptide was dissolved in $2.87 \mathrm{~mL}$ oxidation buffer, oxidized with $287 \mu \mathrm{L}$ of $200 \mathrm{mM}$ $\mathrm{NaNO}_{2}$, and diluted into $67 \mathrm{~mL}$ of $10 \mathrm{mM}$ MPAA in water/acetonitrile (1: 3, v/v), which was prepared by diluting $3.35 \mathrm{~mL}$ of $200 \mathrm{mM}$ MPAA solution in $200 \mathrm{mM}$ phosphate buffer, $6 \mathrm{M}$ $\mathrm{Gn} \cdot \mathrm{HCl}$, pH 6.9 with $64 \mathrm{~mL}$ of water/acetonitrile (1: 3, v/v). After $2.0 \mathrm{mg}$ of citric acid was added to the reaction mixture, the excess of acetonitrile was evaporated and the remaining solution was diluted with $95 \% \mathrm{~A} / 5 \% \mathrm{~B}$ to a total of $40 \mathrm{~mL}$. RP-HPLC purification followed by lyophilization yielded $6.5 \mathrm{mg}$ (60\% yield) of the desired carbamothioate as a white powder (Fig. S33). 


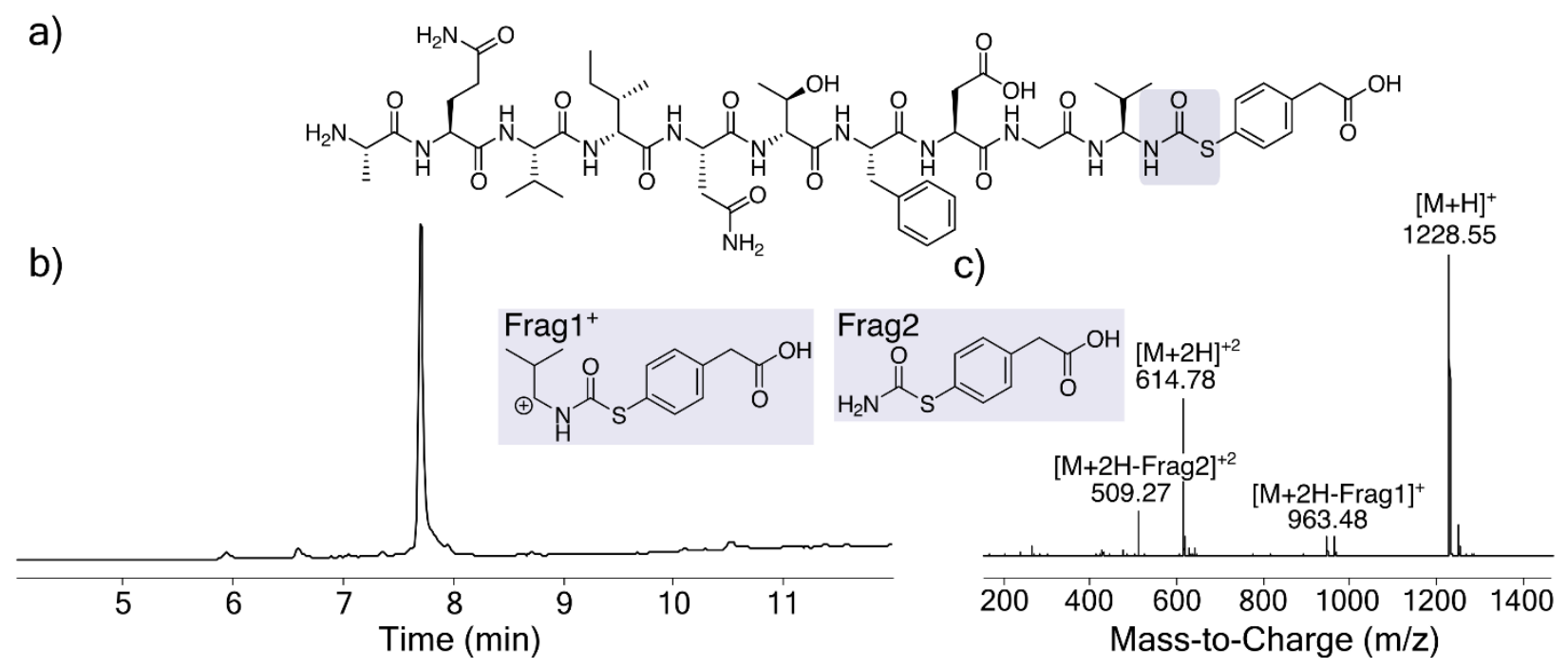

Figure S33. HPLC-MS (TIC) chromatogram (b) for the purified carbamothioate peptide $\mathrm{H}_{2} \mathrm{~N}-\mathrm{Ala}-\mathrm{Gln}$-Val-Ile-Asn-Thr-Phe-AspGly-Val-NH-COS- $\mathrm{C}_{6} \mathrm{H}_{4}-\mathrm{CH}_{2}-\mathrm{COOH}$ with the peptide structure shown in a). c) MS of the compound with major peaks assigned. ESI-induced peptide fragment Frag1 is postulated to exist in a linear form as drawn. Calc. monoisotopic mass $=1227.56$ Da.

\subsection{8. $\mathrm{H}_{2} \mathrm{~N}$-Ala-Gln-Val-Ile-Asn-Thr-Phe-Asp-Gly-Val-CONHNH${ }_{2}+$ methanol}

$10.3 \mathrm{mg}$ peptide was dissolved in $3.11 \mathrm{~mL}$ oxidation buffer, oxidized with $311 \mu \mathrm{L}$ of 200 $\mathrm{mM} \mathrm{NaNO}$, and diluted into $72 \mathrm{~mL}$ of water/methanol (1: 19, v/v, 0.1\% TFA added). After 2.1 $\mathrm{mg}$ of citric acid was added to the reaction mixture, the excess of acetonitrile was evaporated and the remaining solution was diluted with $95 \% \mathrm{~A} / 5 \% \mathrm{~B}$ to a total of $40 \mathrm{~mL}$. RP-HPLC purification followed by lyophilization yielded $6.9 \mathrm{mg}$ ( $66 \%$ yield) of the desired semicarbazide as a white powder (Fig. S34).

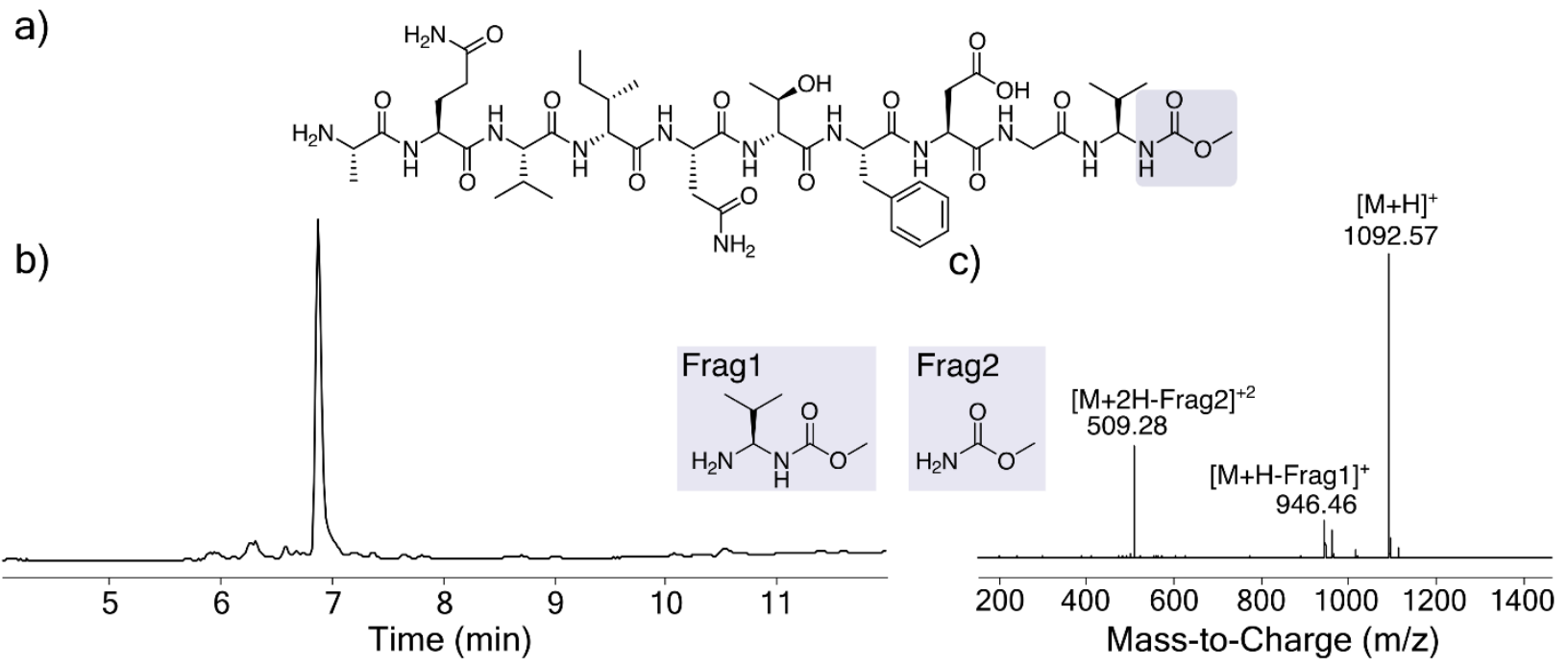


Figure S34. HPLC-MS (TIC) chromatogram (b) for the purified semicarbazide peptide $\mathrm{H}_{2} \mathrm{~N}-\mathrm{Ala}-\mathrm{Gln}$-Val-Ile-Asn-Thr-Phe-AspGly-Val-NH-COOMe with the peptide structure shown in a). c) MS of the compound with major peaks assigned. ESI-induced peptide fragment Frag1 is postulated to exist in a linear form as drawn. Calc. monoisotopic mass = 1091.56 Da.

\subsection{9. $\mathrm{H}_{2} \mathrm{~N}$-Ala-Gln-Val-Ile-Asn-Thr-Phe-Asp-Gly-Val-CONHNH $\mathrm{C}_{2}+$ ethanol}

$1.0 \mathrm{mg}$ peptide was dissolved in $0.30 \mathrm{~mL}$ oxidation buffer, oxidized with $30 \mu \mathrm{L}$ of $200 \mathrm{mM}$ $\mathrm{NaNO}_{2}$, and diluted into $7.0 \mathrm{~mL}$ of water/ethanol (1: 19, v/v, $0.1 \%$ TFA added). The purification of the carbamate peptide was not attempted; RP-HPLC yield as estimated from the TIC chromatogram integration was $70 \%$.

a)

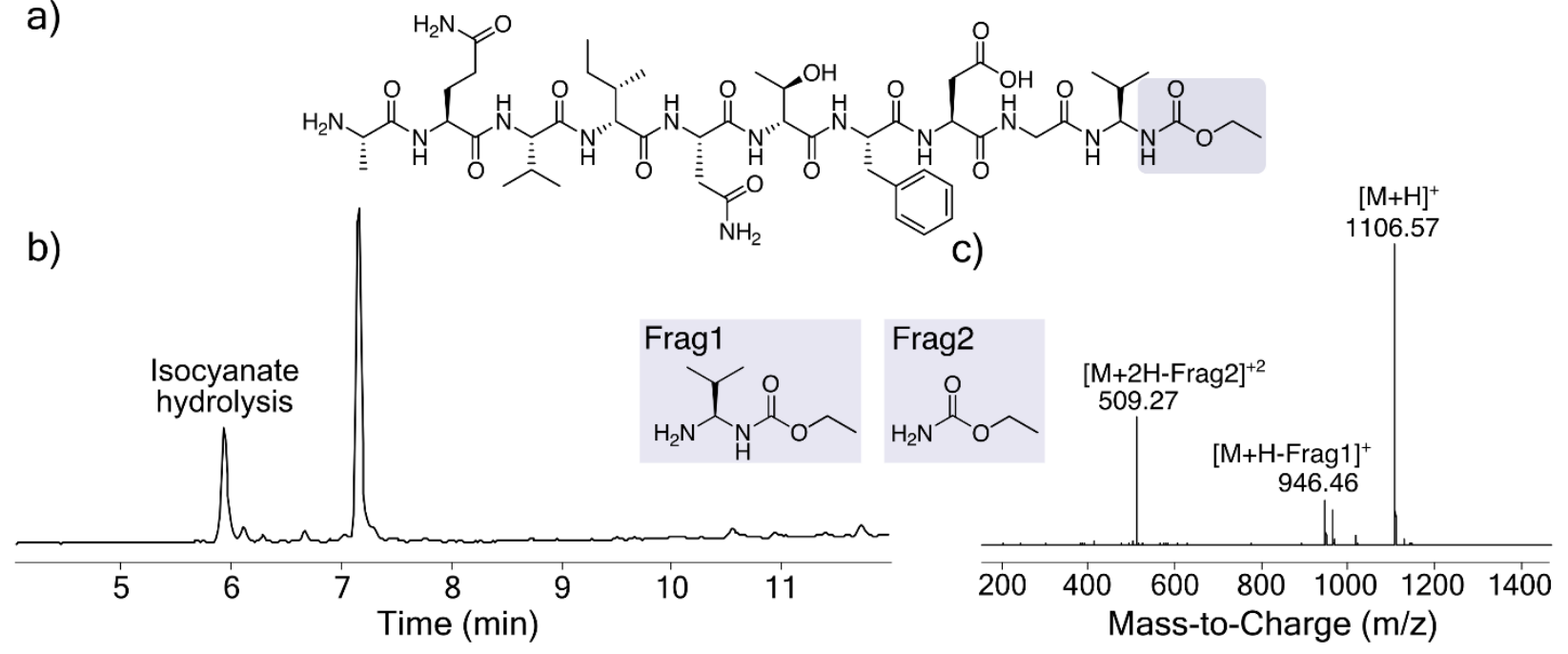

Figure S35. HPLC-MS (TIC) chromatogram (b) for the purified carbamate peptide $\mathrm{H}_{2} \mathrm{~N}$-Ala-Gln-Val-Ile-Asn-Thr-Phe-Asp-GlyVal-NH-COOEt with the peptide structure shown in a). c) MS of the compound with major peaks assigned. ESI-induced peptide fragment Frag1 is postulated to exist in a linear form as drawn. Calc. monoisotopic mass = 1105.57 Da.

\subsection{Establishing the optimum nucleophile concentration for different peptide isocyanates}

Correct nucleophile concentrations are crucial for the success of the conjugation. Here, we sought to compare optimum nucleophile concentrations for different peptides. To accomplish this we compared the MPAA conjugation results for two peptide hydrazides bearing different $\mathrm{C}$ terminal residues: $\mathrm{H}_{2} \mathrm{~N}$-Ala-Gln-Val-Ile-Asn-Thr-Phe-Asp-Gly-Val-CONHNH${ }_{2}$ and $\mathrm{H}_{2} \mathrm{~N}$-AlaArg-Val-Ile-Asn-Thr-Phe-Asp-Gly-Tyr-CONHNH$H_{2}$. MPAA was chosen as a nucleophile sensitive to changes in concentration, i.e. there is a very narrow window of MPAA concentrations where conjugation to the isocyanate is high yielding $(\sim 5-20 \mathrm{mM})$. For 
comparison, conjugation to perfluorophenylhydrazine is high yielding in the range 5-200 $\mathrm{mM}$. Reactions were performed under standard conditions described in section 5.3. Reaction with $\mathrm{H}_{2} \mathrm{~N}$-Ala-Gln-Val-Ile-Asn-Thr-Phe-Asp-Gly-Val-CONHNH${ }_{2}$ were performed at $17{ }^{\circ} \mathrm{C}$; with $\mathrm{H}_{2} \mathrm{~N}$-Ala-Arg-Val-Ile-Asn-Thr-Phe-Asp-Gly-Tyr-CONHNH 2 - at $57{ }^{\circ} \mathrm{C}$. The results of HPLCMS analysis are summarized in Fig. S36.

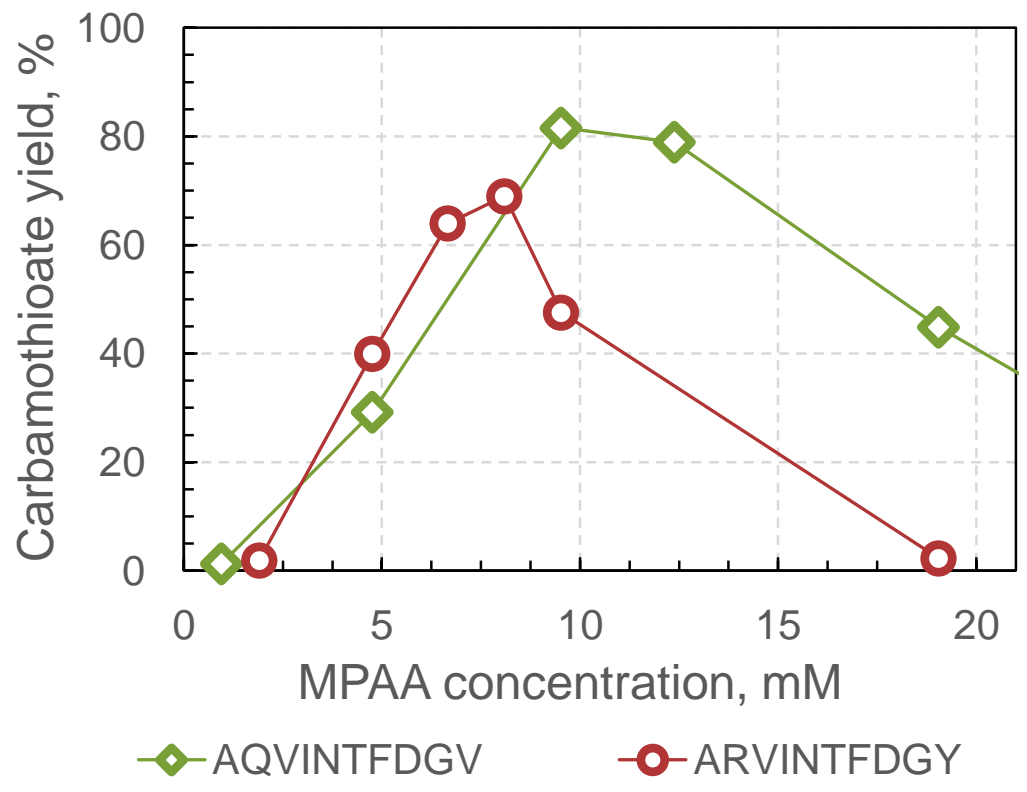

Figure S36. The plot of carbamothioate yield as a function of MPAA concentration for 2 peptides. Yields were obtained from HPLC-MS analysis; reactions were performed under standard (S. I. 5.3) conditions.

The MPAA concentration leading to the maximum carbamothioate yield was similar for the two peptides: $8.5 \mathrm{mM}$ MPAA for $\mathrm{H}_{2} \mathrm{~N}$-Ala-Arg-Val-Ile-Asn-Thr-Phe-Asp-Gly-Tyr-CONHNH 2 versus $10 \mathrm{mM}$ for $\mathrm{H}_{2} \mathrm{~N}$-Ala-Gln-Val-Ile-Asn-Thr-Phe-Asp-Gly-Val-CONHNH 2 . Thus, we concluded that the optimum nucleophile concentration is similar for different peptide isocyanates.

\subsection{Experiment to detect racemization during the conjugation}

To confirm that the Curtius rearrangement and all other steps in the process do not lead to racemization of the C-terminal residue we compared conjugation products formed from two peptide diastereomers: $\mathrm{H}_{2} \mathrm{~N}$-Ala-Gln-Val-Ile-Asn-Thr-Phe-Asp-Gly-Val ${ }^{\mathrm{L}}-\mathrm{CONHNH}_{2}$ and $\mathrm{H}_{2} \mathrm{~N}$ Ala-Gln-Val-Ile-Asn-Thr-Phe-Asp-Gly-Val ${ }^{\mathrm{D}}-\mathrm{CONHNH}_{2}$. Both reactions were performed under standard conditions (section 5.3) using perfluorophenylhydrazine as a nucleophile at $17^{\circ} \mathrm{C}$. To 
resolve diastereomeric semicarbazides (conjugation products) we performed HPLC-MS analysis with the following gradient: $5 \% \mathrm{~B}^{\prime}$ in $\mathrm{A}^{\prime}$ for $2 \mathrm{~min}, 5-65 \% \mathrm{~B}^{\prime}$ in $\mathrm{A}^{\prime}$ ramping linearly over $70 \mathrm{~min}$, $65 \% \mathrm{~B}^{\prime}$ in $\mathrm{A}^{\prime}$ for 1 minute. Diastereomers were resolved on HPLC, and each reaction led to the formation of a single diastereomer (Fig. S37). We concluded that the whole process is indeed racemization-free.

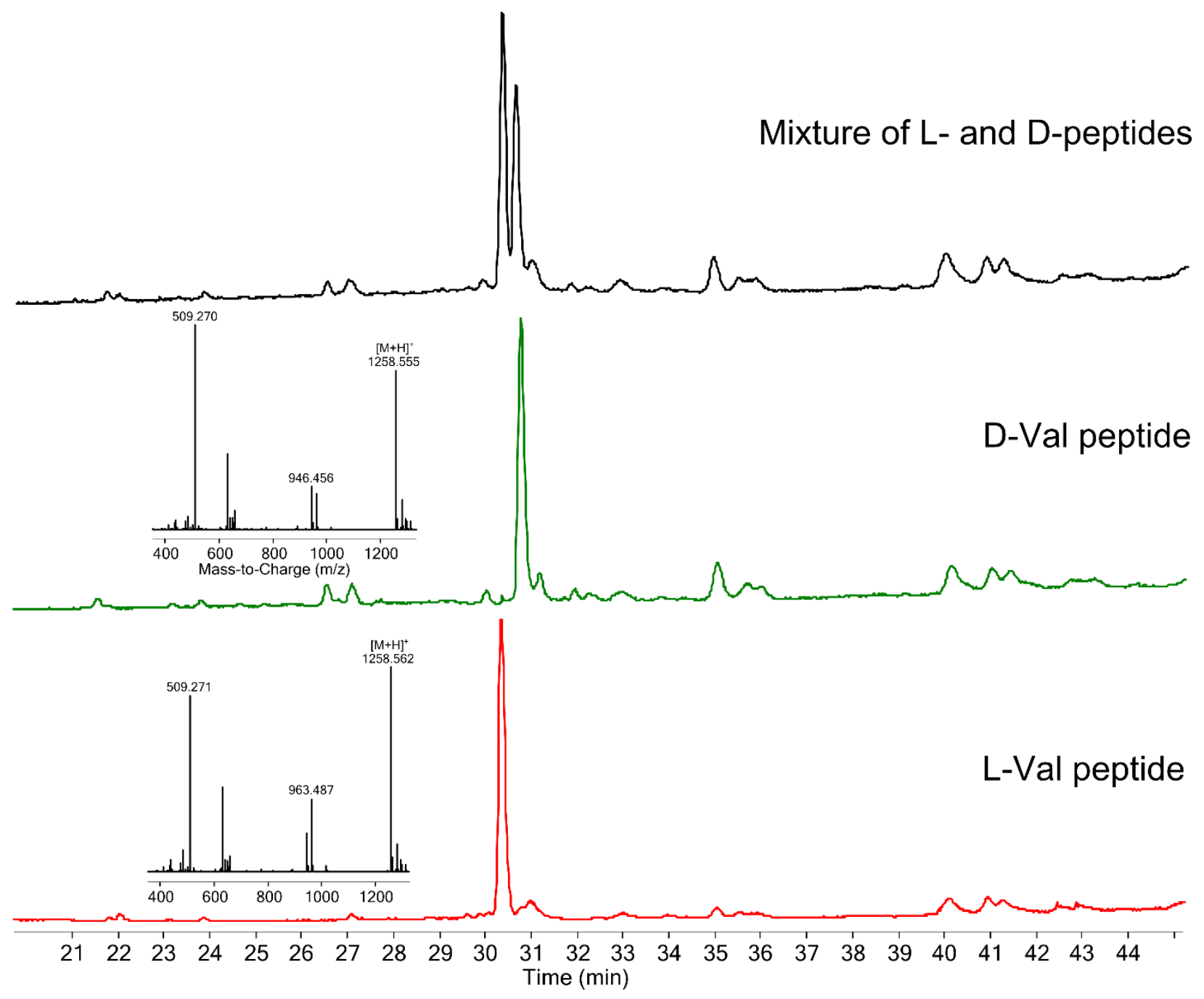

Figure S37. HPLC-MS (TIC) chromatograms for diastereomeric $\mathrm{H}_{2} \mathrm{~N}-\mathrm{Ala}-\mathrm{Gln}-\mathrm{Val}-\mathrm{Ile}-\mathrm{Asn}-\mathrm{Thr}-\mathrm{Phe}-\mathrm{Asp}^{\mathrm{G}} \mathrm{Gly}^{\mathrm{L}}{ }^{\mathrm{L}} \mathrm{Val}_{-\mathrm{CONHNH}} \mathrm{CON}$ and $\mathrm{H}_{2} \mathrm{~N}$-Ala-Gln-Val-Ile-Asn-Thr-Phe-Asp-Gly- ${ }^{\mathrm{D}}$ Val-CONHNH 2 oxidation/conjugation reaction with MS insets for main products (semicarbazides). 


\subsection{Additional data for some C-terminal amino scan experiments}

All reactions described in this section were performed under standard conditions (section 5.3) using $20 \mathrm{mM}$ perfluorophenylhydrazine as a nucleophile at $57^{\circ} \mathrm{C}$, except in case of $\mathrm{H}_{2} \mathrm{~N}$ Ala-His-Val-Ile-Asn-Thr-Phe-Asp-Gly-Thr-CONHNH$H_{2}$ the reaction was at $17^{\circ} \mathrm{C}$.

Peptides with C-terminal Thr and Ser amino acids conjugated poorly to nucleophiles. The reactions resulted in formation of products $17 \mathrm{Da}$ less massive than starting hydrazides. We postulated that these products stem from intramolecular cyclization of isocyanates to C-terminal side chains, resulting in formation of oxazolidin-2-ones. The HPLC-MS trace of one of these reactions is demonstrated in Figure S38.

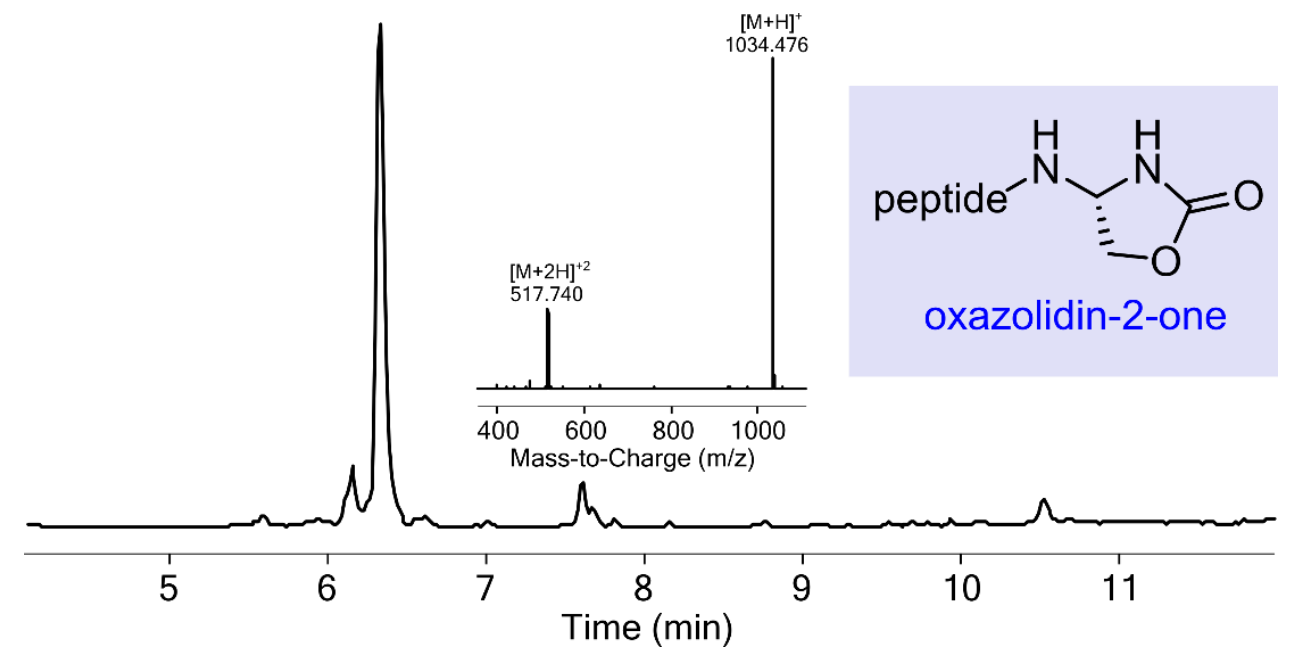

Figure S38. HPLC-MS (TIC) chromatogram for $\mathrm{H}_{2} \mathrm{~N}-\mathrm{Ala}-\mathrm{Asn}$-Val-Ile-Asn-Thr-Phe-Asp-Gly-Ser-CONHNH 2 oxidation/conjugation reaction with MS inset for the main product.

Peptides with C-terminal His and Glu also conjugated poorly to perfluorophenylhydrazine. $\mathrm{H}_{2} \mathrm{~N}$-Ala-Val-Val-Ile-Asn-Thr-Phe-Asp-Gly-His-CONHNH${ }_{2}$ and $\mathrm{H}_{2} \mathrm{~N}$-Ala-Leu-Val-Ile-AsnThr-Phe-Asp-Gly-Glu-CONHNH 2 both showed significant products 14 Da less massive than the starting hydrazide, which were presumably the C-terminal carboxylate formed from hydrolysis of the azide (Fig. S39, a). We hypothesized that in both cases the azide cyclized to the Cterminal residue's side-chain, and then this cyclic intermediate was hydrolyzed to give the carboxylate (Fig. S39, b). To test this possibility, we performed oxidation/thioesterefication of $\mathrm{H}_{2} \mathrm{~N}$-Ala-Leu-Val-Ile-Asn-Thr-Phe-Asp-Gly-Glu-CONHNH${ }_{2}$ under the standard conditions described in Fang, Li et al. Angew. Chem. Int. Ed. 2011, 50, 7645 -7649. As shown in Figure 
$S 39 c$, the reaction yielded the carboxylate and two thioester isomers. When $\mathrm{H}_{2} \mathrm{~N}-\mathrm{Ala}-\mathrm{Val}-\mathrm{Val}-$ Ile-Asn-Thr-Phe-Asp-Gly-His-CONHNH 2 was subject to the same oxidation/thioesterefication conditions, a significant amount of the carboxylate was observed, which is not typical for peptides bearing other C-terminal amino acids. These data are consistent with our initial hypothesis that azides of His and Glu cyclize with their side-chains. Protection of glutamic acid as a cyclohexyl ester eliminated the formation of the carboxylate, as described in the next section.

a)

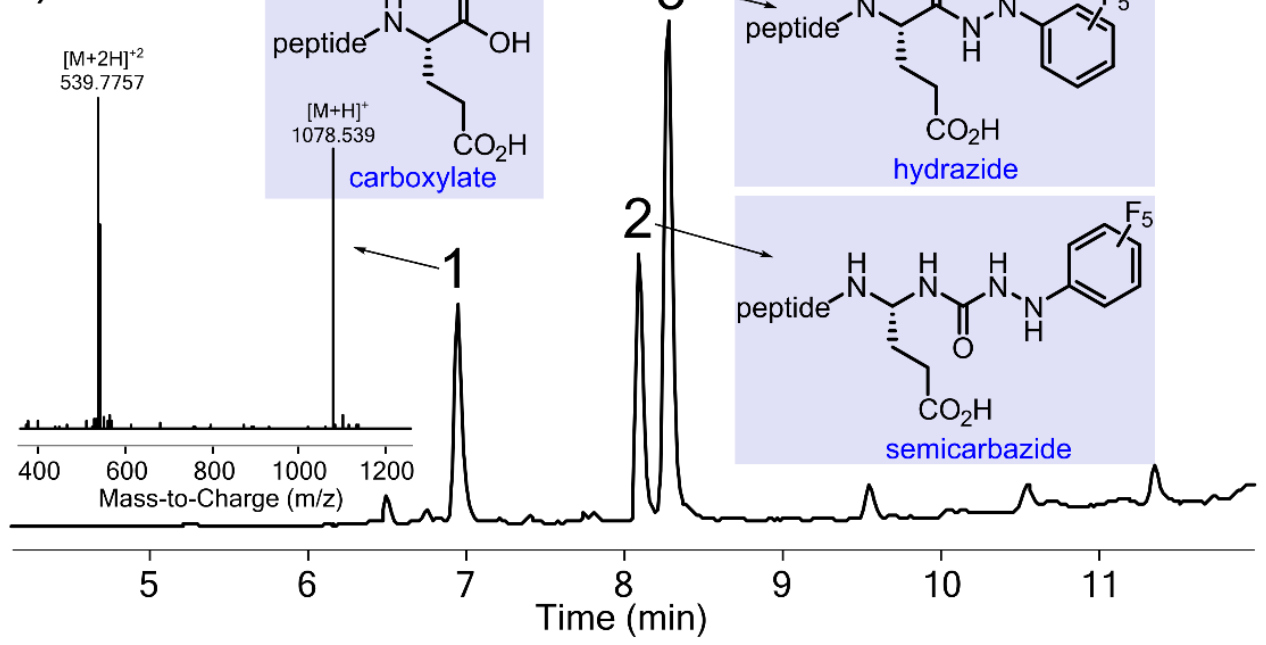

b)

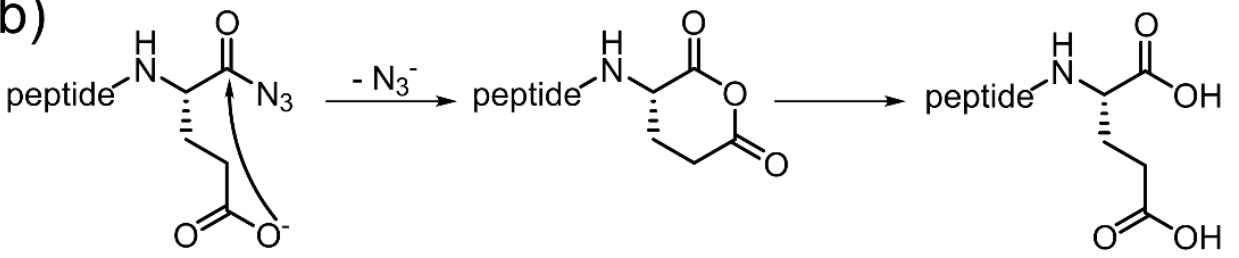

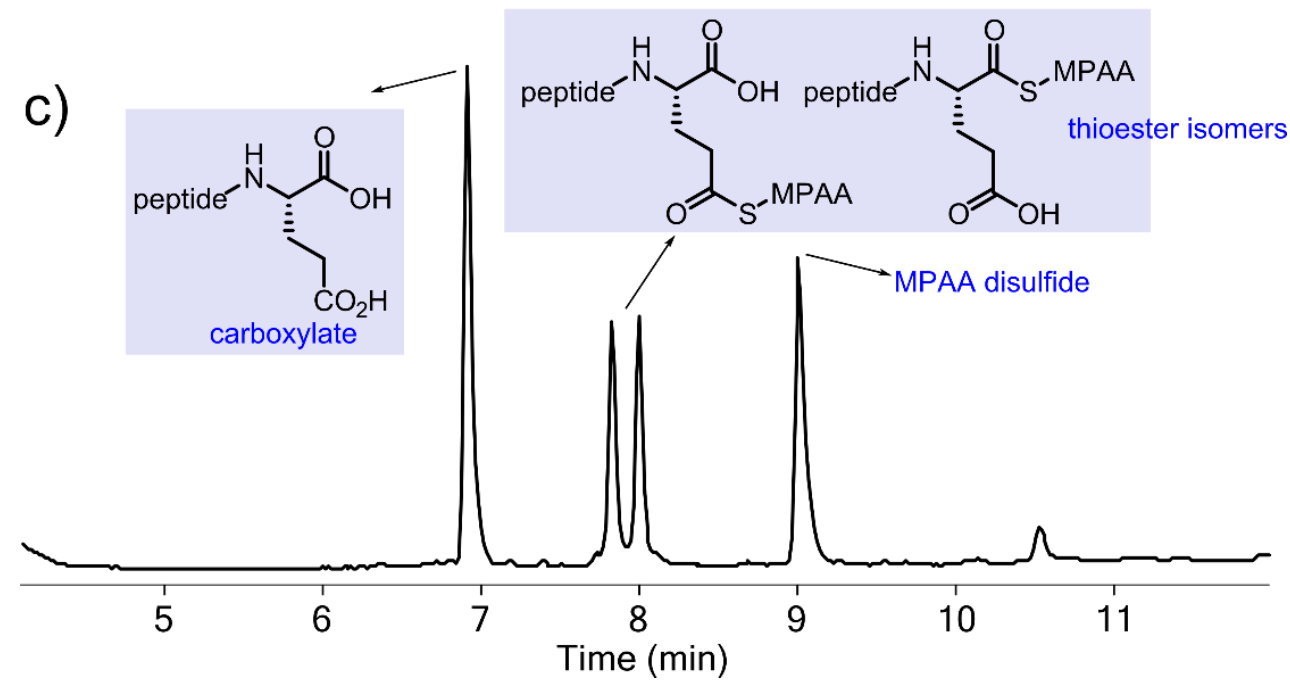


Figure S39. a) HPLC-MS (TIC) chromatogram for $\mathrm{H}_{2} \mathrm{~N}-\mathrm{Ala}-\mathrm{Leu}-\mathrm{Val}-\mathrm{Ile}-\mathrm{Asn}-\mathrm{Thr}-\mathrm{Phe}-\mathrm{Asp}-\mathrm{Gly}_{\mathrm{G}} \mathrm{Glu}-\mathrm{CONHNH} 2$ oxidation/conjugation reaction with MS inset for carboxylate. b) A proposed scheme for carboxylate formation. c) HPLC-MS (TIC) chromatogram for $\mathrm{H}_{2} \mathrm{~N}$-Ala-Leu-Val-Ile-Asn-Thr-Phe-Asp-Gly-Glu-CONHNH${ }_{2}$ oxidation/thioesterefication reaction (200 mM MPAA).

\subsection{Conjugation of perfluorophenylhydrazine to longer peptides}

To study the applicability of our method to longer peptides, we performed oxidation/isocyanate conjugation for two barnase fragments: 26-mer $\mathrm{H}_{2} \mathrm{~N}-{ }^{14} \mathrm{Cys}^{-39}$ Val$\mathrm{CONHNH}_{2}$ and $37-\mathrm{mer} \mathrm{H}_{2} \mathrm{~N}-{ }^{40} \mathrm{Cys}(\mathrm{Acm})-{ }^{76} \mathrm{Glu}(\mathrm{Cy})-\mathrm{CONHNH}_{2}$. Full sequences in one letter codes were:

\section{$\mathrm{H}_{2} \mathrm{~N}-C D Y L Q T Y H K L P D N Y I T K S E A Q A L G W V-C O N H N_{2}$ and}

$\mathrm{H}_{2} \mathrm{~N}$ - (Acm) CSKGNLADVAPGKS IGGDIFSNREGKLPGKSGRTWRE (CY) - $\mathrm{CONHNH}_{2}$.

Perfluorophenylhydrazine was used as a nucleophile and reactions were performed under standard (section 5.3) conditions at $57^{\circ} \mathrm{C}$. HPLC-MS traces of the crude reaction mixtures are displayed in Figure S40. 

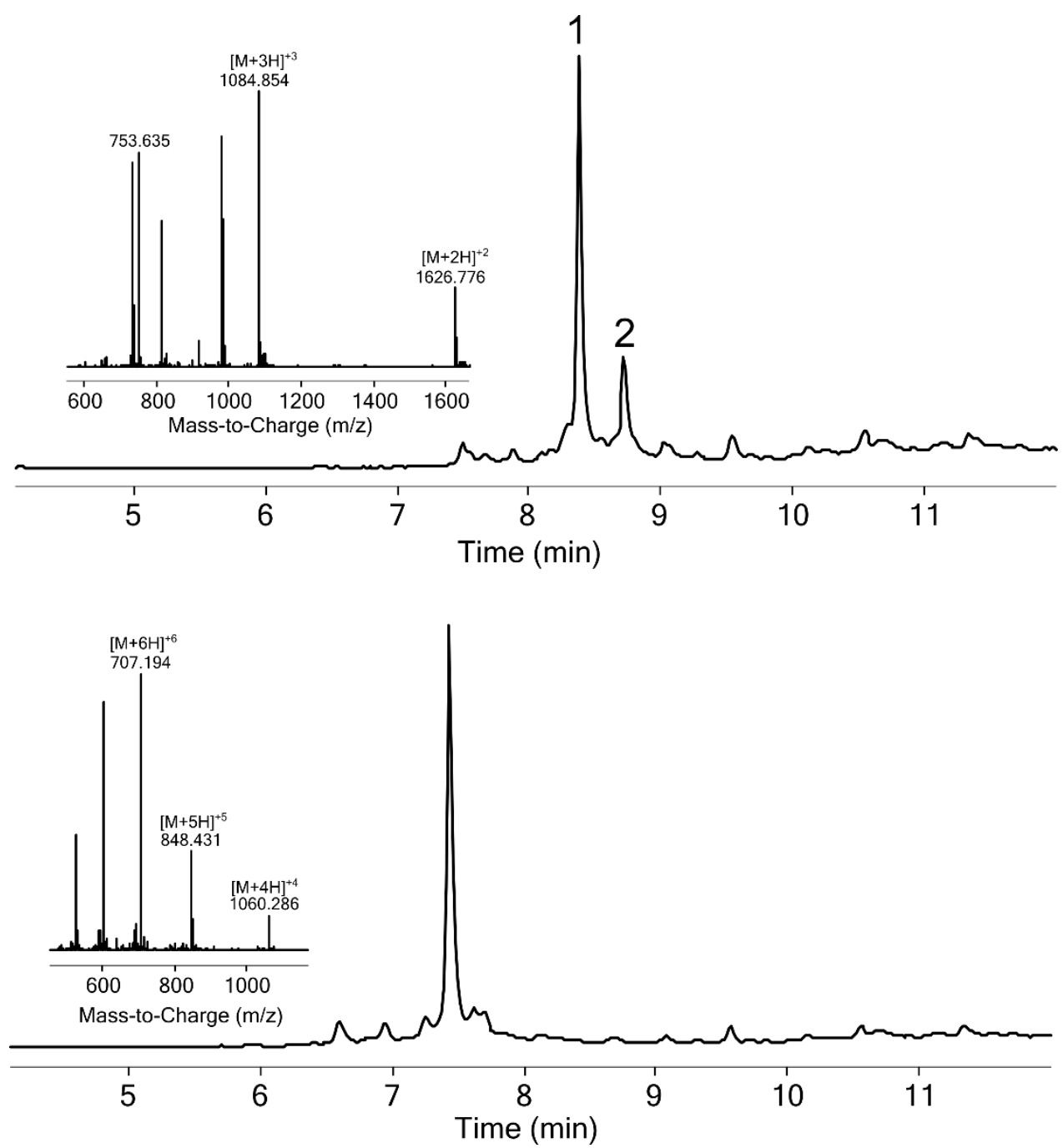

Figure S40. HPLC-MS (TIC) chromatograms for oxidation/conjugation reactions with the barnase fragments $\mathrm{H}_{2} \mathrm{~N}_{-}{ }^{14} \mathrm{Cys}-{ }^{39}$ Val$\mathrm{CONHNH}_{2}$ (26 residues, top) and $\mathrm{H}_{2} \mathrm{~N}-{ }^{40} \mathrm{Cys}(\mathrm{Acm})-{ }^{76} \mathrm{Glu}(\mathrm{Cy})-\mathrm{CONHNH} 2$ (37 residues, bottom). Top: peak 1 corresponds to the expected semicarbazide conjugation product with MS inset of the peak apex displayed on the left (calc. monoisotopic mass = $3250.5 \mathrm{Da}$ ). Peak 2 is an intermolecular disulfide of the conjugation product. Bottom: the main peak is the expected conjugation product with the MS inset of the peak apex on the left. (calc. monoisotopic mass $=4235.0 \mathrm{Da}$ )

\subsection{Sortase A mediated ligation of peptide hydrazide to $\mathrm{LF}_{\mathrm{N}}-\mathrm{DTA}$}

$\mathrm{LF}_{\mathrm{N}}$-DTA protein was expressed and purified as previously described (Ling, Policarpo et al. J. Am. Chem. Soc. 2012, 134, 10749-10752). To produce a C-terminal protein hydrazide we employed a Sortase $\mathrm{A}^{*}$ mediated ligation of $\mathrm{H}_{2} \mathrm{~N}$-Glys-Leu-Glu-Ile-CONHNH $\mathrm{H}_{2}$ to $\mathrm{LF}_{\mathrm{N}}$-DTALeu-Pro-Ser-Thr-Gly2-His5. Ligation was carried out under the following conditions: a mixture of $300 \mu \mathrm{l}$ Tris buffer (125 mM Tris, $100 \mathrm{mM} \mathrm{NaCl}, 1 \mathrm{mM} \mathrm{CaCl}_{2}$, pH 7.5) containing $38 \mu \mathrm{M}$ $\mathrm{LF}_{\mathrm{N}}$-DTA, $350 \mu \mathrm{M}$ peptide hydrazide, $2.5 \mu \mathrm{M}$ Sortase $\mathrm{A}^{*}$, and $80 \mu \mathrm{l}$ Ni-NTA beads was 
incubated at $17^{\circ} \mathrm{C}$ for 30 minutes while nutating gently. Afterwards, the reaction mixture was centrifuged at $13000 \mathrm{rpm}$ for 5 minutes. The beads were washed two times with Tris buffer (150 $\mu \mathrm{l}$ ), and then with $40 \mathrm{mM}$ imidazole in Tris buffer. The washes were combined with the reaction supernatant and concentrated over a Amicon Ultra-4 Ultracel-10K centrifugation filter. To remove excess peptide hydrazide and imidazole, the protein solution was subject to buffer exchange into Tris buffer. The reaction was analyzed with HPLC-MS to confirm complete formation of the desired C-terminal protein hydrazide. The MS spectrum of the resulting protein was deconvoluted using the maximum entropy algorithm to obtain deconvoluted the protein spectrum in Figure 541 .

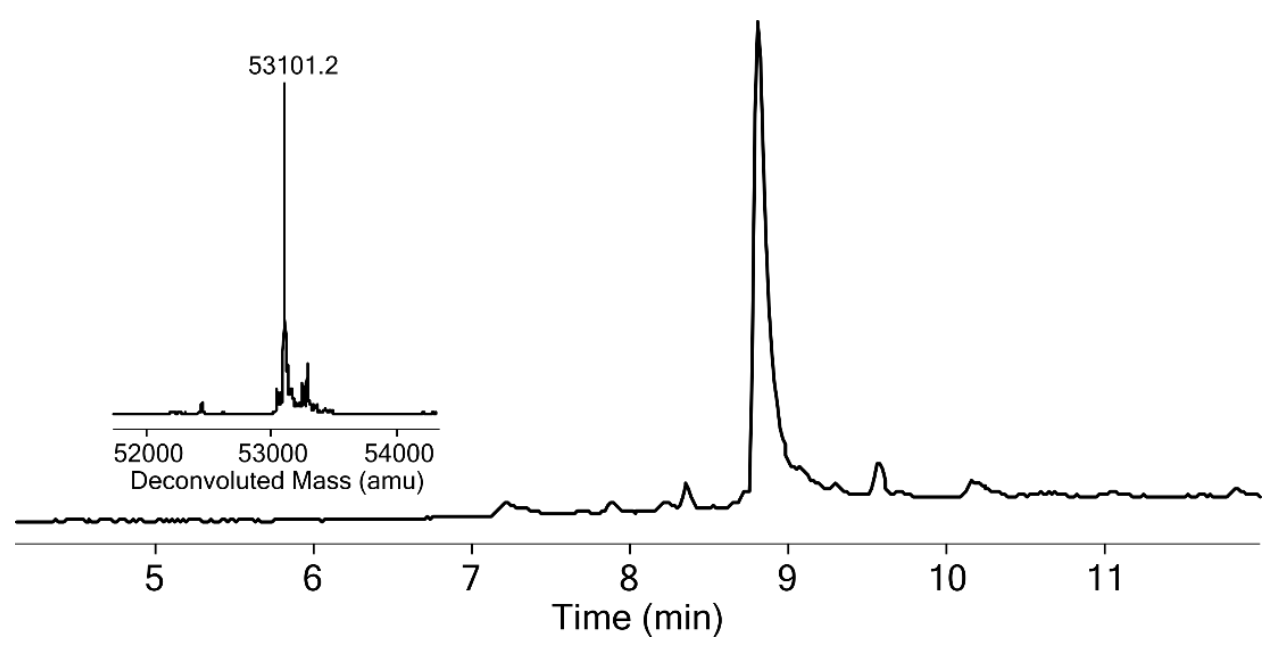

Figure S41. HPLC-MS (TIC) chromatogram for LF $\mathrm{N}_{\mathrm{N}}$-DTA-Leu-Pro-Ser-Thr-Gly5-Leu-Glu-Ile-CONHNH 2 obtained via Sortase A* mediated ligation of $\mathrm{H}_{2} \mathrm{~N}-\mathrm{Gly} 5$-Leu-Glu-Ile-CONHNH 2 to $\mathrm{LF}_{\mathrm{N}}-\mathrm{DTA}$-Leu-Pro-Ser-Thr-Gly2-His5. The deconvoluted MS on the left was obtained using the maximum entropy algorithm. 